\title{
Synergistic and concentration-dependent toxicity of multiple heavy metals compared with single heavy metals in Conocarpus lancifolius
}

\author{
Amina Redha ${ }^{1} \cdot$ Redha Al-Hasan $^{1} \cdot$ Mohammad Afzal $^{1,2}$ (D) \\ Received: 24 July 2019 / Accepted: 28 December 2020 / Published online: 14 January 2021 \\ (C) The Author(s) 2021
}

\begin{abstract}
While heavy metals (HMs) naturally occur in soil, anthropogenic activities can increase the level of these toxic elements. Conocarpus lancifolius Engl. (Combretaceae) was investigated as a potential phytoremediator of soils contaminated with HM containing crude oil. This study assessed the potential of C. lancifolius (CL), a locally available plant species in Kuwait, for resolving local issues of the $\mathrm{HM}$-contaminated soils. The absorption, accumulation, and distribution of three toxic $\mathrm{HMs}(\mathrm{Cd}, \mathrm{Ni}$, and $\mathrm{Pb}$ ) and essential metals ( $\mathrm{Fe}, \mathrm{Mg}$, and metalloid $\mathrm{Se}$ ) were examined, and their role in plant toxicity and tolerance was evaluated. Conocarpus lancifolius plants were exposed to two different concentrations of single and mixed HMs for 30 days. The accumulation of HMs was determined in the roots, leaves, stems, and the soil using ICP/MS. Biomass, soil pH, proline and protein content, and bioaccumulation, extraction, and translocation factors were measured. The bioaccumulation, extraction, and transcription factors were all $>1$, indicating CC is a hyperaccumulator of HM. The HM accumulation in CL was concentrationdependent and depended on whether the plants were exposed to individual or mixed HMs. The C.C leaves, stems, and roots showed a significant accumulation of antioxidant constituents, such as proline, protein, $\mathrm{Fe}, \mathrm{Mg}$, and Se. There was an insignificant increase in the soil $\mathrm{pH}$, and a decrease in plant biomass and a significant increase in protein, and osmoprotective-proline as a result of the interaction of mixed heavy metals that are more toxic than single heavy metals. This study indicates that C. lancifolius is a good candidate for phytoremediation of multiple HM-contaminated soils. Further studies to establish the phyto-physiological effect of multiple heavy metals are warranted.
\end{abstract}

Keywords Conocarpus lancifolius $\cdot$ Heavy metal $\cdot$ Bioaccumulation factor $\cdot$ Enrichment factor $\cdot$ Translocation factor $\cdot$ Oxidative stress

\section{Introduction}

During the extraction and transport of crude oil, heavy metals (HMs) become an important component of the soil, and because HMs are nondegradable, they persist in the environment and they impose potential human health and ecological risks (Lian et al. 2019; Yan et al. 2020). In response to oxidative stress (OS), HMs cause a steady rate of the production of reactive oxygen species (ROS) causing extensive cellular damage to the live organisms (Gao

Responsible Editor: Elena Maestri

Mohammad Afzal

1 Department of Biological Studies, Faculty of Science, Kuwait University, Kuwait City, Kuwait

2 Gainesville, USA et al. 2019; Hasanuzzman et al. 2020). The production of ROS reduces the antioxidant defenses, which negatively affects cytoplasmic enzymes and causes a serious impairment of cellular structure, ultimately leading to physicochemical changes in the plants (Shahid et al. 2014; Nanda and Agrawal 2016; Laxa et al. 2019). HMs can also damage the cell wall proteins and nuclear DNA (Nanda and Agrawal 2016), and interact with the central $\mathrm{Mg}^{2+}$ in chlorophyll, thereby disrupting photosynthetic activity. The damage can be aggravated by altering the morphology and growth dynamics of plants and the damage places reliance on the rate of accumulation of the HMs (Küpper et al. 2006). Plants have dissimilar HM-accumulation capacities, and species with higher amassing potentials, such as Brassica juncea (Brassicaceae) subsp. Integrifolia, Var. strumata and B. napus, have been used for the phytoremediation of HM-contaminated ecosystems (Mourato et al. 2015). 
Phytoremediation of soil is cost-effective involving green chemistry, but its success depends on many factors, such as plant species, soil texture, and its pH (Farrag et al. 2011). In response to abiotic stresses, plant roots exude a diverse array of chemicals that may support unique rhizospheric microbial communities, essential for plant survival, and growth (Skowronska et al. 2020). Therefore, an adequate balance is established between rhizospheric bacteria, HMs, and root exudates, which determines the uptake of HMs and their translocation by the roots to the overground parts of the plant. The root hairs increase the root surface area and play a primary role in the plant-soil interactions that can regulate the hydrodynamics and absorption of HMs from the soil.

The most important parameters for the effective phytoremediation include rapid biomass production and effective translocation of pollutants into all parts of the plant (Rezvani and Zaefarian 2011). Mahajan and Kuashal (2018) have described four criteria for phytoremediation: (a) a rapid growth rate, (b) a high biomass, (c) a hairy deep-root system, and (d) a bioaccumulation factor (BAF) $>1$.

Conocarpus lancifolius tree is native to riverine areas of Somalia, Djibouti, Yemen, horn of Africa, Arabian Peninsula, and South Asia. Before the 1991 Gulf war, this tree was not found in Kuwait desert. For greenery projects undertaken by the government of Kuwait, C. lancifolius was introduced into Kuwait from Djibouti. In the harsh environment of Kuwait desert, the plant has thrived well and now it is found along all main boulevards of the city, parks, and is used as a green fence around private houses. It is also trimmed into various attractive shapes that enhance its grace. C. lancifolius has a fast growth, long hairy roots, high availability, approval by the local population, and due to its large biomass that provides substantial quantities of shading material.

A major catastrophe occurred in land, marine, and coastal environments during the Gulf war in 1991, when 6-8 million barrels of crude oil were spilled into the marine environment of Kuwait waters. In addition, setting oil wells ablaze propelled massive amounts of soot and toxic gasses into the atmosphere, causing one of the biggest man-made ecological disasters in human history. The spilling of crude oil imposed deleterious effects on the ecosystem, due to the persistent toxicity of several HMs present in oil residues. However, after thirty years of the war, along the Wafra road (an oil production area), the soil marginally contains $\mathrm{Cd}$ at $0.027 \mathrm{mg} \mathrm{kg}^{-1}$ soil, $\mathrm{Ni}$ at $120.96 \mathrm{mg} \mathrm{kg}^{-1}$ soil, and $\mathrm{Pb}$ at $2.9 \mathrm{mg} \mathrm{kg}^{-1}$ soil, levels well below the contaminated soils (Kostecki and Behbehani 1995; Wuana and Okieimen 2011; Chinedu and Chukwuemeka 2018).

In 2009, we initiated a systematic study on $C$. lancifolius and discovered that the plant was resistant to drought conditions and high salinity, and it could endure high desert temperatures (Redha et al. 2011, 2019). These characteristics, fast growth rate, and its large biomass make this plant a good candidate for phytoremediation studies involving HMcontaminated soil. In polluted soils, metals are not present as single elements, but they are a mixture of metals affecting flora and fauna of the environment. Although the effect of heavy metals on $C$. lancifolius irrigated with wastewater has been reported (Rasheed et al. 2019), the objective of this investigation was to demonstrate the assimilation of multimetals by this plant and upregulation of its antioxidant defenses. Since $C$. lancifolius meets all the benchmarks of a good phytoremediator, we decided to examine its incorporation of multi-metals from the oil-polluted soil of Kuwait.

\section{Materials and methods}

\section{Plant materials and growth conditions}

All chemicals used in this study were purchased from VWR International (Solsbury, UK). According to WRB classification, the Kuwait local soil is Regosol in the arid desert and Flavisol in some northern coastal areas.

Plants were obtained from the Public Authority for Agriculture and Fish Resources (PAAFR; a government organization in the State of Kuwait). The growth and maintenance conditions of the plants were followed as reported earlier (Redha et al. 2019). Local sandy soil and peat moss (3:1 v/v; $3.5 \mathrm{~kg}$ ) were used for plant growth in plastic pots $(9 \times 6 ")$. Seventy plants of uniform height, with 10-12 leaves and a single shoot, were maintained at $25^{\circ} \mathrm{C}$, with a relative humidity of $45-55 \%$, and a white light intensity of $150 \mathrm{mmol}$ quanta $\mathrm{m}^{-2} \mathrm{~s}^{-1}$ for $30 \mathrm{~d}$. Plants were divided into 11 groups $(\mathrm{a}-\mathrm{k})$ with six plants in each group. Group-a served as the control without $\mathrm{HM}$ solution treatment. Plants in groups $\mathrm{b}-\mathrm{k}$ were irrigated with $50 \mathrm{~mL}$ of 25 or $50 \mu \mathrm{mol} \mathrm{L}{ }^{-1}$ of the single $\mathrm{HM}$ solutions (Cadmium (II) nitrate tetrahydrate, Nickle (II) nitrate hexahydrate, and Lead (II) nitrate salts), or $50 \mathrm{~mL}$ of the $25 \mu \mathrm{mol} \mathrm{L}{ }^{-1}$ mixed HM solutions on alternate days. Plant groups-b, $d$, and $f$ were treated with $25 \mu \mathrm{mol} \mathrm{L}^{-1}$ of Cd, $\mathrm{Pb}$, and $\mathrm{Ni}$, respectively; plant groups-c, e, and g were treated with $50 \mu \mathrm{mol} \mathrm{L}^{-1}$ of $\mathrm{Cd}$, $\mathrm{Pb}$, and $\mathrm{Ni}$, respectively, and plant groups $\mathrm{h}-\mathrm{k}$ were treated with $25 \mu \mathrm{mol} \mathrm{L}{ }^{-1}$ of mixed $\mathrm{HMs}(\mathrm{Cd}-\mathrm{Pb}, \mathrm{Cd}-\mathrm{Ni}$, $\mathrm{Ni}-\mathrm{Pb}$, or $\mathrm{Cd}-\mathrm{Ni}-\mathrm{Pb}$, respectively). Plants did not survive when irrigated with mixed HMs at $50 \mu \mathrm{mol} \mathrm{L}{ }^{-1}$. Leaf and stem samples were collected on days 10,20 , and 30 of the experiment, and root samples were collected on day 30 . The plant samples were thoroughly washed with distilled water to remove any soil particles, and oven-dried at $70^{\circ} \mathrm{C}$ for $24 \mathrm{~h}$ (Thermo Fisher Scientific, Rochford, UK, Model ELED 3625A-1) to a constant weight. The dried plant tissues were powdered and weighed. The $\mathrm{HMs}(\mathrm{Cd}, \mathrm{Pb}$, and $\mathrm{Ni})$ and essential metals (Fe, $\mathrm{Mg}$, and metalloid Se) in $1 \mathrm{~g}$ of powdered plant tissue were measured by inductively coupled plasma/mass 
spectrometry-mass spectrometry (ICP/MS, details under ICP/ MS measurements).

\section{Microwave digestion of the plant material}

Plant material samples were prepared according to Kisku et al. (2000), using both high temperature and pressure to ensure total HM extraction. Dry powdered plant material (1 g, root or leaf) was placed in the reaction vessel and a mixture of concentrated nitric acid $(65 \%)$ and concentrated perchloric acid $(4: 1 \mathrm{v} / \mathrm{v})$, was added to the reaction vessel (EPA method 3052). The reaction vessel was sealed and heated in a microwave oven (Gallenkamp 300 plus electric oven, Loughborough, UK). The digestion was completed at (180$1000^{\circ} \mathrm{C}$ ) for $20 \mathrm{~min}$, with ventilation at $20 \mathrm{~min}$. The reaction contents were transferred into a $25 \mathrm{~mL}$ polypropylene flask, and the digestion vessel was thoroughly washed with milli-Q water, and this was mixed with the sample digestion reaction contents. Reagent blanks were prepared using the same methods as for the samples. A high-purity concentrated nitric acid $\left(\mathrm{HNO}_{3} ; 69-70 \%\right.$, extra-quality, Fisher Scientific, and certified 30\% hydrogen peroxide (Analytical Reagent Grade, BDH Ltd, Poole, UK) were used. Double distilled deionized water (Milli-Q Millipore $18.2 \mathrm{M} \Omega \mathrm{cm}^{-1}$ resistivity) was used for all dilutions. Plant samples were prepared in triplicate (18 samples from each group), and the respective means and standard errors of the means ( \pm SEMs) were used in analyses.

\section{ICP-MS measurement of $\mathrm{Cd}, \mathrm{Pb}, \mathrm{Ni}, \mathrm{Fe}, \mathrm{Mg}$, and $\mathrm{Se}$ in leaves, roots, and soil samples}

Dried leaf, stem, root, and soil samples (1 g each) were individually used to determine the HM contents, and results were expressed as $\mu \mathrm{g} \mathrm{g}^{-1}$. A Perkin Elmer inductively coupled plasma-mass spectrometer (ICP-MS-Perkin Elmer Optima 7300DV, San Francisco, CA, USA) was used to detect HMs. We report the accumulation of HMs in the treatment groups relative to the HM levels in the control.

The ICP-MS system was calibrated with certified reference materials (CRM), Rhodium (Rh), and Rhenium (Re) nitrate salts ( Sigma-Millipore-Supelco, USA). The reagent blank solution contained $1 \%$ concentrated $\mathrm{HNO}_{3}$. Mixed standard solutions (reagent blanks) contained six elements ( $\mathrm{Mg}, \mathrm{Se}, \mathrm{Fe}$, $\mathrm{Ni}, \mathrm{Pb}$, and $\mathrm{Cd}$ ). The background interferences from the plasma gasses, i.e., air entrainment and solvent, were corrected by subtraction of reagent blank signals. To monitor the drift of the instrument, the CRM element Yttrium, $\mathrm{Y}\left(\mathrm{NO}_{3}\right)_{3}$ (SigmaMillipore-Supelco, USA), was used as an internal standard.

The instrumental operating parameters were as follows: plasma gas flow, $15 \mathrm{~L} \mathrm{~min}^{-1}$; nebulizer gas flow, $0.97 \mathrm{~L}$ $\min ^{-1}$; lens voltage, variable; dual detector; cross flow nebulizer; flow rate of sample, $1 \mathrm{~mL} \mathrm{~min}^{-1}$; and spectra scanning, peak hopping. The instrument calibration was done using standard solutions, and a calibration curve was created. Quality control checks, internal calibration verifications (standards from different vendors), internal calibration blanks, continuing calibration verifications, and blank samples were run before and after the analyses of experimental samples. The $\mathrm{HM}$ content $\left(\mathrm{mg} \mathrm{kg}^{-1}\right.$ ) was calculated using the following equation:

$\mathrm{HM}$ content $=$ Instrument reading $\times 50 \times 10$

where 50 is the final sample volume, and 10 is the dilution factor.

\section{Measurement of bioaccumulation, enrichment, and translocation factors}

The BAFs, EFs, and TFs were used as markers to appraise the capacity of plants to eliminate HMs from the soil and plantsoil interactions (Kisku et al. 2000; Kumar et al. 2018; Sampanpanish and Nanthavong 2019). These factors were calculated according to Rezvani and Zaefarian, (2011), using equations $1-3$. All metrics were measured on the $30^{\text {th }}$ day of the experiments. The source of the HMs in the control plants was the contaminated soil in which the plants were grown.

$\mathrm{BAF}=\frac{\text { Metal content in contaminated leaf } / \text { stem }}{\text { Metal content in contaminated soil }}$

$\mathrm{EF}=\frac{\text { Metal content in contaminated leaf } / \text { stem }}{\text { Metal content in control leaf }}$

$\mathrm{TF}=\frac{\text { Metal content in contaminated leaf } / \text { stem }}{\text { Metal content in contaminated roots }}$

Accumulator and excluder plants accumulate metals at $>1 \mathrm{mg} \mathrm{kg}^{-1}$ and $<1 \mathrm{mg} \mathrm{kg}^{-1}$, respectively. The BAFs, EFs, and TFs for hyperaccumulators have been reported to be $>1$ (McGrath and Zhao 2003). Hyperaccumulators are known to accumulate 50-500 times more metals than ordinary plants (Chaney et al. 1997).

\section{Soil pH, biomass, proteins, and proline measurements}

Soil samples (20 g) were collected on days 10, 20, and 30 from control pots (without exposure to HMs) and from pots exposed to HMs. Each soil sample was mixed with $40 \mathrm{~mL}$ of distilled/deionized water $(50 \mathrm{~mL})$ for $30 \mathrm{~min}$, and the $\mathrm{pH}$ of the supernatant was measured with a calibrated $\mathrm{pH}$ meter $\mathrm{pH}$ 4 and 7, Cole-Parmer Model 430; Eaton Socon, Saint Neots, 
UK). The $\mathrm{pH}$ was recorded in triplicate (i.e., from three soil samples) per pot, and the mean \pm SEMs were calculated. Biomass was measured by drying six individual plants per treatment at $75^{\circ} \mathrm{C}$ for $48 \mathrm{~h}$, recording their individual weights, and calculating the treatment means \pm SEMs. The total proteins in the freeze-dried plant were measured according to Bradford (1976).

\section{Protein determination}

A standard solution of bovine serum albumin solution (0.1 $\mathrm{mg} / \mathrm{mL}$ ) was prepared, and Bradford reagent (Sigma-Aldrich B6916, St. Louis, MO-63103, USA) was used for all protein assays. Absorbance was taken at $595 \mathrm{~nm}$ and a linear equation $\left(R^{2}=0.9991\right)$ was generated with different concentrations of the standard protein solution, and it was used to calculate protein in the plant extracts prepared as given below.

Fresh freeze-dried plant tissue $(100 \mathrm{mg})$ was homogenized with a polytron homogenizer (PT10/35 GT, Kinenatica, Zaragoza, Spain) in PBS 1X (5 mL) and centrifuged (Bench top, Sorvall ST 8, Thermo Fisher Scientific, Rochford, UK) at $10,000 \mathrm{~g}$ for $15 \mathrm{~min}$. The supernatant was taken and the pellet was twice washed with deionized water and centrifuged. The combined supernatant was diluted with deionized water to make the volume to $100 \mathrm{~mL}$, and its absorbance was used in the linear equation to calculate the protein concentration as $\mu \mathrm{g} / \mathrm{g}$ plant material. This procedure was repeated in triplicate on three different samples of the same plant tissue and SEM was taken.

\section{Proline determination}

Proline was measured using spectrophotometry as described in the literature (Carillo and Gibon 2011, Bergman and Loxley 1970). Briefly, proline standard solution (0.01-0.04 mM) was prepared in ethanol: water $(70: 30 \mathrm{v} / \mathrm{v})$. The reaction mixture was prepared by mixing ninhydrin $1 \%(\mathrm{w} / \mathrm{v})$ in acetic acid $60 \%(\mathrm{v} / \mathrm{v})$ and ethanol 20\% (v/v). The $400 \mu \mathrm{l}$ of standard proline solution was mixed with $100 \mu$ ninhydrin reaction mixture and heated to $95^{\circ} \mathrm{C}$ for $20 \mathrm{~min}$. After cooling and spinning for $1 \mathrm{~min}$ at $2500 \mathrm{rpm}$, the absorbance was taken at $520 \mathrm{~nm}$. A standard curve was obtained and the generated linear equation $\left(R^{2}=0.9993\right)$ was used to calculate proline in plant extracts.

Plant extract was prepared from $0.5 \mathrm{~g}$ fresh frozen plant tissue, and thawed and homogenized with a polytron homogenizer (PT10/35 GT, Kinematica, Zaragoza, Spain) in $5 \mathrm{~mL}$ ethanol : water $(70: 30 \mathrm{v} / \mathrm{v})$ and centrifuged (PT10/35 GT, Kinematica, Zaragoza, Spain) at $10,000 \mathrm{~g}$ for $15 \mathrm{~min}$. The supernatant was taken and the pellet was twice re-extracted with $5 \mathrm{~mL}$ of the same solvent mixture. The combined supernatant was diluted to $100 \mathrm{~mL}$ with the same solvent mixture. The ninhydrin reaction mixture, prepared as above, $(100 \mu \mathrm{l})$ was mixed with the plant extract $(400 \mu \mathrm{l})$ and absorbance (520 $\mathrm{nm}$ ) was used in the linear equation to calculate proline concentration. This procedure was repeated in triplicate on three different samples and SEM was taken.

\section{Statistical analysis}

A one-way nonparametric ANOVA, followed by NewmanKeuls post hoc analysis, was used for data analysis. A twotailed unpaired Student's $t$-test was used to compare two groups. Each parameter was estimated three times and the mean $\pm \mathrm{SD}$ values were recorded. The independent variables were the time of exposure and metal concentration. All statistical analyses were performed using the GraphPad Prism software (Version 8.4.3; San Diego, CA, USA), and $p$ values < 0.05 were considered statistically significant. All tests were conducted on the data collected on the $30^{\text {th }}$ day of the experiment.

\section{Results}

The treated C. lancifolius plants survived single metal treatment at both 25 and $50 \mu \mathrm{mol} \mathrm{L}^{-1}$ for $30 \mathrm{~d}$. However, the plants

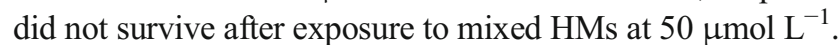
Groups b, d, and f exposed to $25 \mu \mathrm{mol} \mathrm{L}{ }^{-1}$, and groups c, e, and g exposed to $50 \mu \mathrm{mol} \mathrm{L}{ }^{-1}$, differed significantly in their heavy metal accumulation ( $p<0.0001$, F values: $\mathrm{Pb} 3168, \mathrm{Ni}$ 1640, Cd 275.6; ANOVA). The Newman-Keuls multiple comparison test showed a significant difference (ANOVA, $p$ $<0.0001, \mathrm{~F}$ ratio $=275.6, \mathrm{df}=17$ ) between the control plants (group-a) and the experimental groups-b, $d$, and f and groups$\mathrm{c}$, e, and $\mathrm{g}$, in terms of HM accumulation. In all treatment groups exposed to $\mathrm{HMs}$ at $25 \mu \mathrm{mol} \mathrm{L}{ }^{-1}$, the accumulation of HMs was significantly higher in the roots than in the leaves ( $p$ $<0.00001$, ANOVA, $\mathrm{df}=17$ ). Compared with the control plants, plants exposed to single $\mathrm{HMs}$ at $50 \mu \mathrm{mol} \mathrm{L} \mathrm{L}^{-1}$ (groups-c, e, g) had a significantly higher HMs accumulation than those exposed to single HMs at $25 \mu \mathrm{mol} \mathrm{L}^{-1}$ (groups-b, d, f; ANOVA, $p<0.0001$, Bartlett's statistic, 16.64, $\mathrm{df}=2$ ), revealing the effect of HM concentration on HM accumulation both in the leaves and roots. Plants exposed to the mixed HMs at $25 \mu \mathrm{mol} \mathrm{L}^{-1}$ (groups-j-k; Fig. 1b, d) showed an

Fig. 1 Uptake of single/mixed heavy metals in roots and leaves at two different concentrations: Uptake of heavy metals in roots $\mathbf{a}, \mathbf{b}$, leaves $\mathbf{c}, \mathbf{d}$, and stems e after Conocarpus lancifolius plants were exposed to single ( 25 or $50 \mu \mathrm{mol} \mathrm{L}^{-1}$ ) and mixed heavy metals (HMs) $25 \mu \mathrm{mol} \mathrm{L}^{-1}$. d The metal enclosed in brackets represents the metal that was measured in the mixture. Data were compared with the respective control data and a oneway ANOVA was used to assess differences between the means and $p$ values. Bars and error bars represent means \pm SEMs. Ctr, control group; the number after the metal symbol represents the concentration in $\mu \mathrm{mol} \mathrm{L} \mathrm{L}^{-1} ; * * p$, significant differences $(p<0.01)$; *** $p$, highly significant differences $(p<0.001)$ 


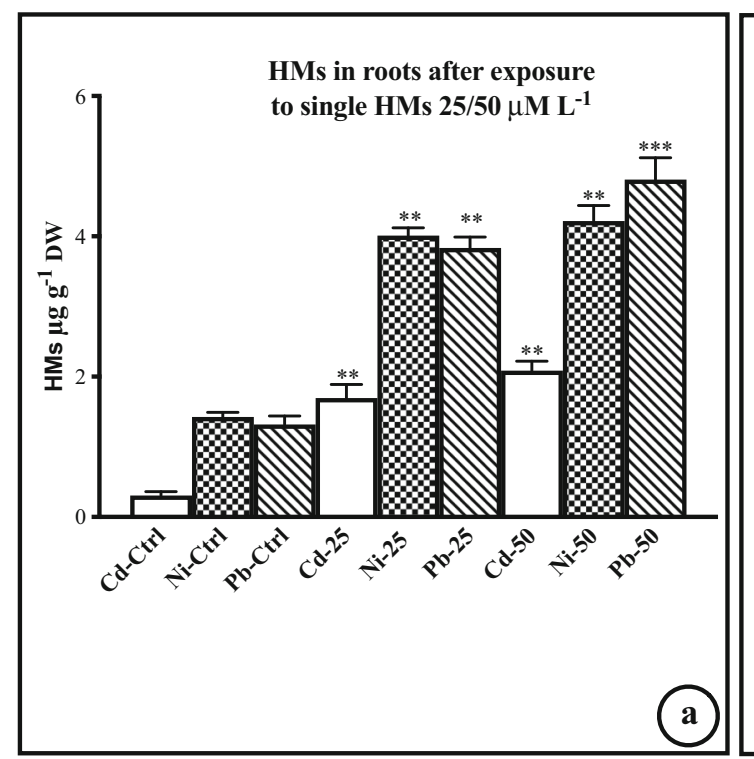

HMs in roots after exposure

to mixed HMs $25 \mu M \mathrm{~L}^{-1}$

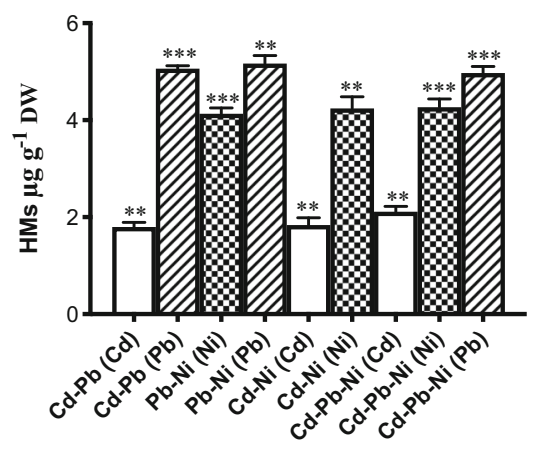

a)

(b)
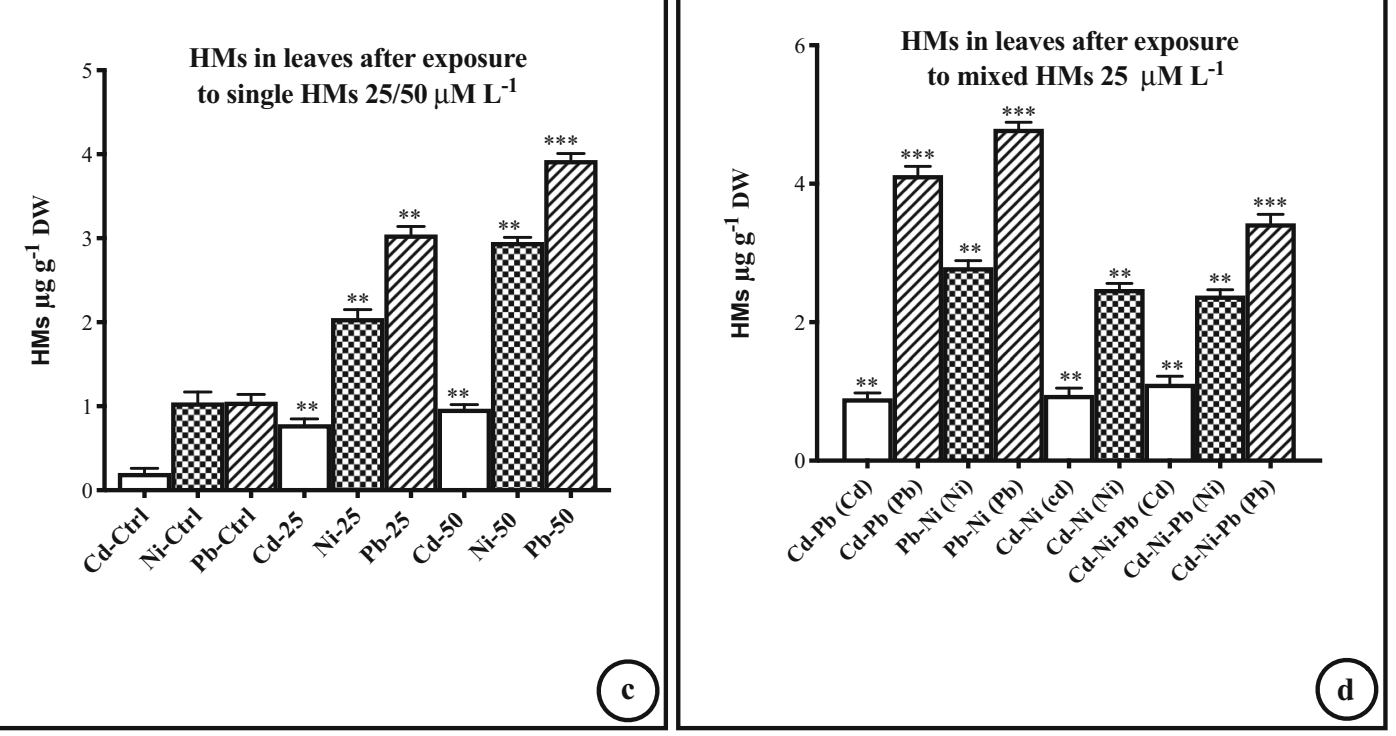

(c)

(d)

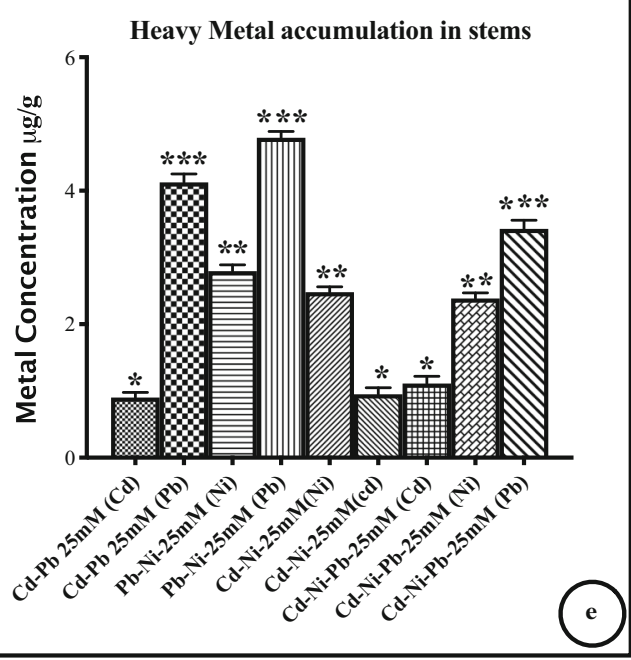


increase in HM accumulation that was similar to plants exposed to single HMs at $50 \mu \mathrm{mol} \mathrm{L}^{-1}$ (groups-c, e, g; Fig. $1 \mathrm{a}, \mathrm{c})$. The accumulation of the HMs in roots was significantly higher (ANOVA, $p=0.0001, \mathrm{~F}$ ratio $=2911, \mathrm{df}_{\mathrm{bc}}$ (between columns $)=2, \mathrm{df}_{\mathrm{wc}}($ within column $)=15$, total $\left.\mathrm{df}=17\right)$ than in leaves and stems (Fig. 1a, b, e). Treatment of plants with mixed HM at a higher concentration of $50 \mu$ l, the plants did not survive. Comparing the control group with group-k (which was provided with a mixture of three HMs), group-k had highly significant absorption of HMs (ANOVA, $p<$ $0.0001, \mathrm{~F}$ ratio $18296, \mathrm{df}_{\mathrm{bc}}=5, \mathrm{df}_{\mathrm{wc}}=30$, total $\mathrm{df}=35$ ) of HMs.

Compared with the control group, $\mathrm{Cd}$ showed the highest percentage accumulation when used as a single $\mathrm{HM}$ at 25 or $50 \mu \mathrm{mol} \mathrm{L}^{-1}$ (groups-b, c) or as part of a mixture of HMs at $25 \mu \mathrm{mol} \mathrm{L}{ }^{-1}$ (Table 1; groups-h, i, k). Concentration of $\mathrm{Cd}$ was greater in the roots than in the leaves (ANOVA, $p<$ $0.0001, \mathrm{~F}$ ratio $=18296, \mathrm{df}_{\mathrm{bc}}=5, \mathrm{df}_{\mathrm{wc}}=30$, total $\mathrm{df}=35$ ) when it was used as a single HM or when admixed with other HMs. However, in plants exposed to $\mathrm{Pb}$ in mixture or alone (groups-d, e, h, j, k; Table 1), both leaves and roots had a higher percentage accumulation, than plants exposed to $\mathrm{Ni}$ in mixture or alone (groups-f, g, i, j, k; Table 1). These results indicate that the order of $\mathrm{HM}$ accumulation in the plant was $\mathrm{Cd}>\mathrm{Pb}>\mathrm{Ni}$.

Compared with the control plants, the accumulation of $\mathrm{Pb}$ in the treatment groups was significantly higher (ANOVA, $p<$ $0.0001, \mathrm{~F}$ ratio $=2305, \mathrm{df}_{\mathrm{bc}}=29, \mathrm{df}_{\mathrm{wc}}=25$, total $\left.\mathrm{df}=29\right)$ in roots than in leaves and stems of all treated plants (Fig. 1a, $\mathrm{c}, \mathrm{e})$. The BAFs and TFs suggested that $\mathrm{Pb}$, as a single $\mathrm{HM}$ or admixed with other HMs, was better absorbed in the roots and transported to the leaves (Table 2, 3). Thus, an exposure of the plants to $\mathrm{Pb}$ alone at 25 or $50 \mu \mathrm{mol} \mathrm{L}{ }^{-1}$ (groups-d, e, respectively, compared with the control group), caused a significantly higher Pb BAF ( $t$-test, $p=0.0198, t=3.77, \mathrm{df}=5$, Table 2 ). The TF ratio of $\mathrm{Pb}$ (Table 3 ) was also significantly higher in group-d than in the control ( $t$-test, $p=0.0001, t=$ 23). However, a comparison of the TFs for Cd (group-b, c) and $\mathrm{Pb}$ (group-d, e; Table 3), indicated that $C$. lancifolius is a better accumulator or transporter of $\mathrm{Pb}$. The TF ratio for $\mathrm{Pb}$ was also significantly higher ( $t$-test, $p=0.004, t=5.1, \mathrm{df}=5$ ) after the plants were exposed to mixed HMs (groups $\mathrm{h}-\mathrm{k}$ compared with the control Table 3). This was also supported by a highly significant difference in HM accumulation between the control and groups-b, $d, f$ and groups-c, e, g.

The BAFs and EFs were used to assess the potential of plants to purge metals from the soil. In plants exposed to a mixture of two HMs containing Pb at $25 \mu \mathrm{mol} \mathrm{L}^{-1}$, (groups-h, $\mathrm{j}$, leaf; Table 1), $\mathrm{Pb}$ facilitated the accumulation of $\mathrm{Cd}$ without affecting the accumulation of Ni. Relative to the levels in the control, when plants were exposed to mixed HMs containing Cd (groups-i-k; Table 1), the leaf BAF for Cd increased from $36.3 \%$ (in group-i) to $58.4 \%$, and $62.3 \%$ in group-k, respectively. The presence of $\mathrm{Pb}$ also raised the leaf $\mathrm{BAF}$ for $\mathrm{Ni}$ (3.8\%; group-f, $\mathrm{j}, \mathrm{k}$; Table 1). A similar synergistic cytotoxicity of $\mathrm{Pb}$ and $\mathrm{Cd}$ has been reported (Patra et al. 2011). Ni synergistic activity was seen in the BAF for roots (Table 1). The extraction factor (EF) ratios of plants exposed to single or mixed HMs were $>1$ (Table 1). In white-rot fungi, the potentiality of nickel and cadmium has been reported (Noormohamadi et al. 2018).

The TFs $(0.77$ in the control) were significantly higher $(t-$ test, $p=0.0001, t=2.48, \mathrm{df}=5$ ) at 1.66 in plants exposed to $\mathrm{Cd}$ alone at $25 \mu \mathrm{mol} \mathrm{L}{ }^{-1}$ (group-b, Table 3); similarly, TFs were significantly higher ( $t$-test, $p=0.019, t=3.37, \mathrm{df}=5$ ) at 1.7 in plants exposed to $\mathrm{Cd}$ alone at $50 \mu \mathrm{mol} \mathrm{L}^{-1}$ (group-c).

Table 1 Percentage increase in heavy metal accumulation in Conocarpus lancifolius after exposure to single /mixed heavy metals at two different concentration

\begin{tabular}{|c|c|c|c|c|c|c|c|c|c|c|}
\hline \multirow[t]{3}{*}{ Group } & \multirow[t]{3}{*}{ Sample } & \multicolumn{3}{|l|}{ Leaves } & \multicolumn{3}{|l|}{ Stem } & \multicolumn{3}{|l|}{ Roots } \\
\hline & & \multicolumn{3}{|l|}{$\%$ increase } & \multicolumn{3}{|l|}{$\%$ increase } & \multicolumn{3}{|l|}{$\%$ increase } \\
\hline & & $\mathrm{Cd}$ & $\mathrm{Ni}$ & $\mathrm{Pb}$ & $\mathrm{Cd}$ & $\mathrm{Ni}$ & $\mathrm{Pb}$ & $\mathrm{Cd}$ & $\mathrm{Ni}$ & $\mathrm{Pb}$ \\
\hline $\mathrm{a}$ & Control & $0.77 \pm 0.23$ & $0.66 \pm 0.12$ & $0.85 \pm 0.36$ & $0.77 \pm 0.23$ & $0.66 \pm 12$ & $0.85 \pm 0.36$ & $0.77 \pm 0.23$ & $0.66 \pm 0.12$ & $0.85 \pm 0.36$ \\
\hline$b, d, f$ & $\mathrm{Cd}, \mathrm{Pb}, \mathrm{Ni}-25$ & $71.8 \pm 2.1$ & $48.1 \pm 2.2$ & $64.8 \pm 2.4$ & $75.4 \pm 2.9$ & $57.2 \pm 1.9$ & $66.3 \pm 1.2$ & $84.7 \pm 2.4$ & $52.2 \pm 2.8$ & $69.7 \pm 2.5$ \\
\hline $\mathrm{c}, \mathrm{e}, \mathrm{g}$ & $\mathrm{Cd}, \mathrm{Pb}, \mathrm{Ni}-50$ & $76.5 \pm 3.6$ & $62.9 \pm 3.1$ & $72.4 \pm 2.3$ & $78.8 \pm 2.7$ & $71.3 \pm 2.1$ & $75.4 \pm 2.2$ & $86.9 \pm 3.3$ & $55.6 \pm 2.3$ & $76.4 \pm 3.1$ \\
\hline $\mathrm{h}$ & $\mathrm{Cd}-\mathrm{Pb}-25$ & $75.5 \pm 2.9$ & - & $74.0 \pm 3.5$ & $77.3 \pm 1.8$ & - & $77.3 \pm 1.8$ & $84.7 \pm 2.7$ & - & $76.4 \pm 3.7$ \\
\hline $\mathrm{i}$ & $\mathrm{Cd}-\mathrm{Ni}-25$ & $77.1 \pm 3.4$ & $56.4 \pm 3.3$ & - & $70.1 \pm 2.1$ & $60.1 \pm 1.7$ & - & $85.4 \pm 3.1$ & $56.0 \pm 2.1$ & - \\
\hline j & $\mathrm{Pb}-\mathrm{Ni}-25$ & - & $61.4 \pm 2.7$ & $77.4 \pm 3.1$ & - & $62.4 \pm 2.3$ & $80.1 \pm 1.8$ & - & $53.6 \pm 2.5$ & $77.3 \pm 3.3$ \\
\hline $\mathrm{k}$ & $\mathrm{Cd}-\mathrm{Pb}-\mathrm{Ni}-25$ & $80.3 \pm 4.2$ & $54.8 \pm 2.8$ & $68.9 \pm 2.9$ & $84.3 \pm 2.4$ & $60.4 \pm 2.7$ & $75.4 \pm 2.1$ & $86.9 \pm 3.7$ & $55.6 \pm 2.7$ & $76.3 \pm 3.8$ \\
\hline
\end{tabular}

Gr = Group, HM-25 and HM-50 (Gr: b, d, f; Gr: c, e, g, respectively) represent the single heavy metal treatment at concentrations 25 and $50 \mu \mathrm{M} \mathrm{L}{ }^{-1}$, respectively. Mixed HMs (Gr: h-k) were used at $25 \mu \mathrm{M} \mathrm{L}^{-1}$. Data were collected on day 30 and compared with the control group (Gr: a). The data represent means $\pm \operatorname{SEM}(n=6)$ 
สิ่ OO

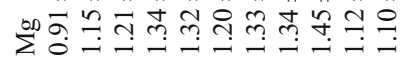

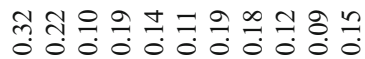
$\mathrm{H}+\mathrm{H} H \mathrm{H}+\mathrm{H} H \mathrm{H}+\mathrm{H} H$

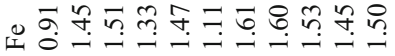

กุ่ $\begin{array}{llllllll}H & H \\ H & H & H & H & H & H & H & H\end{array}$ ڤ 这

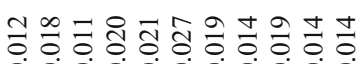

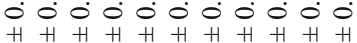
-

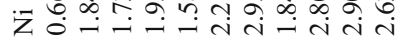

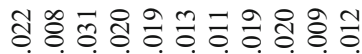

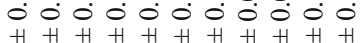
2

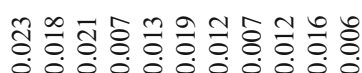

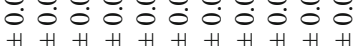

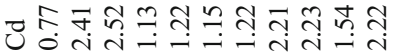

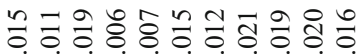

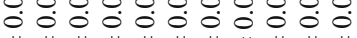
H H H H H H H H H H H

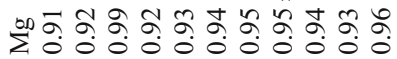

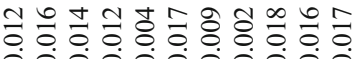

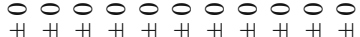

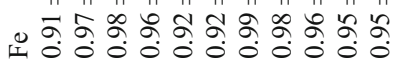

च

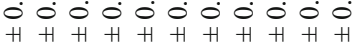

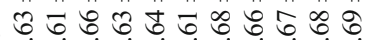

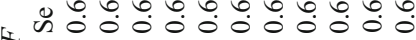
$\underset{\infty}{\infty}$

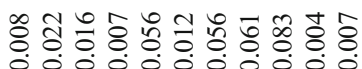

0 z

ㅇํㅇㅊำสำกำ

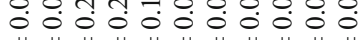
${ }_{H}+H_{H}+H_{H} H_{H} H_{H}$

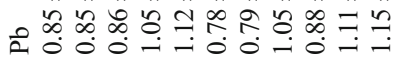

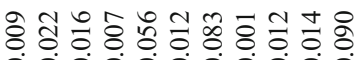

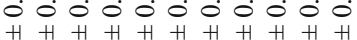

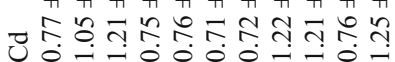

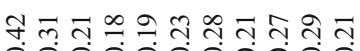

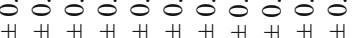

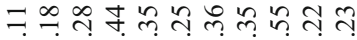

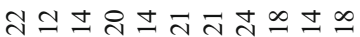
0000000 $\mathrm{H} H \mathrm{H} H \mathrm{H} H \mathrm{H} H \mathrm{H} H \mathrm{H} H$

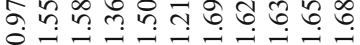

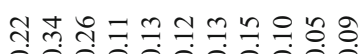
0 o 000 o 000

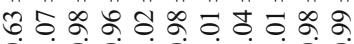
녿

tan-mth-

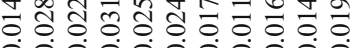
ํำ

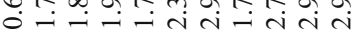

ธิธ $\frac{\infty}{\sigma}$ ปิ

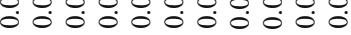
H H H H H H H H H H H

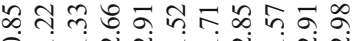

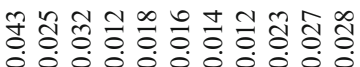

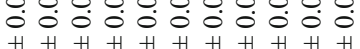

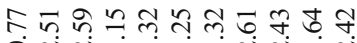

ำ

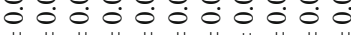
H H H H H H H H H H H б̆

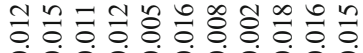

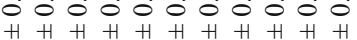

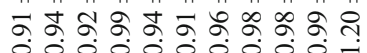

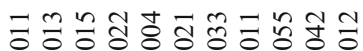
0
0
$H_{H}$

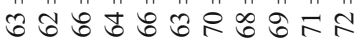
近

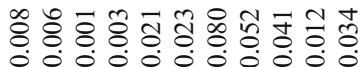

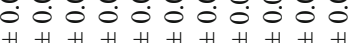

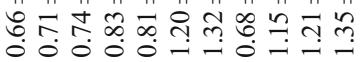

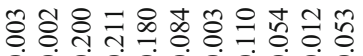
00000000000

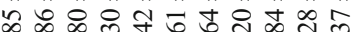

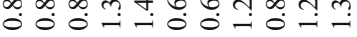

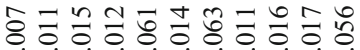

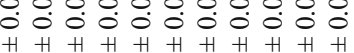

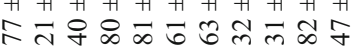

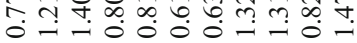
$\begin{array}{llll}H & H \\ 0 & H & H & H\end{array}$ I0000000000.

สิณ

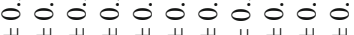

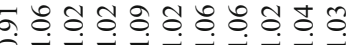
-

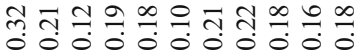

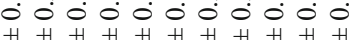

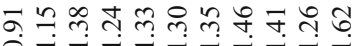

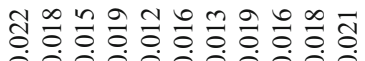

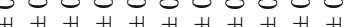

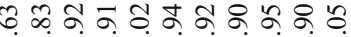

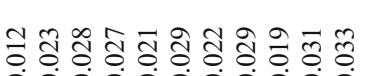

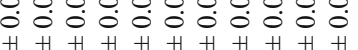

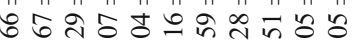
$0-\mathrm{i}$ त त

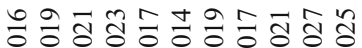

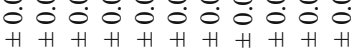
H H H H H H H H H H H

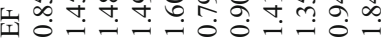

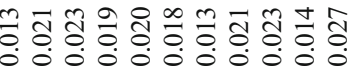
$H_{H} H_{H} H_{H}+H_{H} H_{H}+$

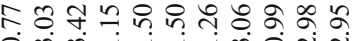

สิธ

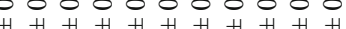

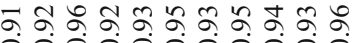
(2)

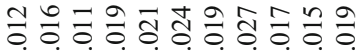
00000000

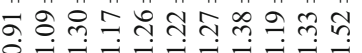

응 융 궁응

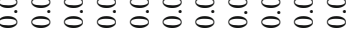
H H H H H H H H H H H

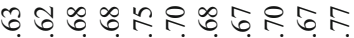
- 0000000000

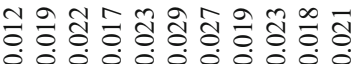
H H H H H H H H H

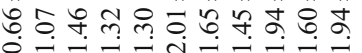

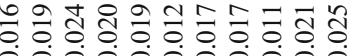
O 0000000000

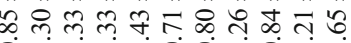

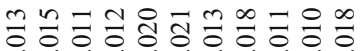

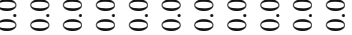
$H_{H}^{H} H^{H} H^{H} H^{H}{ }^{H}$

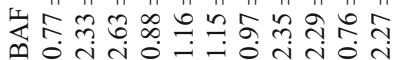

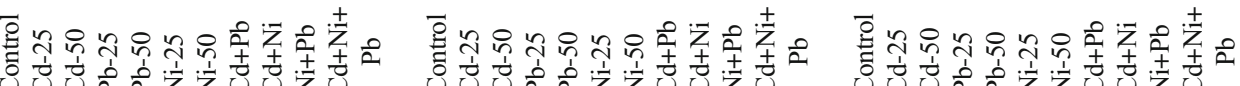
离 藏 
The TFs (Table 3) also showed that Cd significantly improved $\mathrm{Ni}$ translocation (group-i) after the plants were exposed to the $25 \mu \mathrm{mol} \mathrm{L}{ }^{-1}$ mixture of the two HMs ( $t$-test, $p=0.0007, t=$ 12.1, $\mathrm{df}=5$ ). Translocation of the metals, including essential metals (Fe, $\mathrm{Mg}$, and metalloid $\mathrm{Se}$ ), was also significantly higher ( $t$-test, $p<0.02, \mathrm{df}=5$ ) when plants were exposed to a mixture of the three metals (group-k). A higher TF (1.82) was obtained after the plants were exposed to a mixture of the three HMs at $25 \mu \mathrm{mol} \mathrm{L}{ }^{-1}$. This indicated that the mixed metals had a synergistic effect on their translocation in C. lancifolius.

\section{Influence of HMs on soil pH and proline and protein content}

After $30 \mathrm{~d}$ of the exposure to HMs, C. lancifolius showed a non-significant higher soil $\mathrm{pH}$ ( $t$-test, $p=0.1317, t=1.8, \mathrm{df}=$ 5; Fig. 2a-c), and a non-significantly lower biomass ( $t$-test, $p$ $=0.2534, t=1.29, \mathrm{df}=5$; Fig. $2 \mathrm{~d}-\mathrm{f}$ ); however, the levels of defense molecules, such as proteins and proline, were significantly higher than in the control ( $t$-test, $p=0.2910, t=1.18$, df $=5$; Fig. 3a-f).

\section{Discussion}

Our results indicate that mixed HMs had synergistic toxicity even at lower concentrations, compared with single HMs at higher concentrations (Ucuncu et al. 2014). The toxicity of $\mathrm{HMs}$ results from the interaction between heavy metals and secondary metabolites, with the generation of higher OS, which has detrimental effects on the plant growth and development (Zhang et al. 2015; Wang et al. 2018; Zoufan et al. 2018). OS generation is induced by switching on the plant tolerance mechanisms, by producing the antioxidant constituents. Tomašević et al. (2004) reported that plant leaves may be used as good indicators of OS.

The accumulation of all three HMs was observed in the roots and leaves of $C$. lancifolius, indicating that the plant is a multi-HM tolerant shrub. This type of multi-HM accumulation is uncommon in plants and is mainly due to the synergistic toxicities of the HMs (Horvat et al. 2007). However, some plants are known to simultaneously accumulate $\mathrm{Zn}$ and $\mathrm{Cu}$, but the increase in HMs in the vacuolar compartments and cell walls does not significantly damage the essential parts of the cell (Abdelkarim et al. 2019). Therefore, HM accumulation may take place in vacuoles where enzymes are least affected. Alternatively, elements may undergo oxidative modifications, such as the selenite-selenate oxidative transformation (Hawrylak-Nowak 2013) and Cr(VI)-Cr(II, IV); the former is highly toxic to plants while the latter is less toxic) Shanker et al. 2005).

An increase in the accumulation of HMs in C. lancifolius (Fig. 1, Table 1) implies that the plant is a hyperaccumulator of HMs, and that it can be used for the phytoremediation of contaminated soils. In hyperaccumulators, the accumulation of HMs in the roots is followed by the translocation of HMs into the leaves. Consistent with this, HMs accumulated more in the roots (Fig. 1a, b; Table 1) than in the leaves (Fig. 1c, d; Table 1). The higher accumulation of highly toxic $\mathrm{Pb}$ and $\mathrm{Cd}$ shows that $C$. lancifolius preferentially accumulated these HMs. This is because $C$. lancifolius has a high growth rate with a large green crown (Redha et al. 2019). Observations during this study revealed that $C$. lancifolius also has long hairy roots. The wide-spread hairy roots, a large crown, and fast growth are characteristic benchmarks of an HM hyperaccumulator.

Table 3 Translocation factors (TFs) for single/mixed heavy metal exposure in Conocarpus lancifolius

\begin{tabular}{|c|c|c|c|c|c|c|c|}
\hline Group & Exposure & $\mathrm{Cd}$ & $\mathrm{Pb}$ & $\mathrm{Ni}$ & $\mathrm{Se}$ & $\mathrm{Fe}$ & $\mathrm{Mg}$ \\
\hline $\mathrm{a}$ & Control & $0.77 \pm 0.23$ & $0.85 \pm 0.36$ & $0.66 \pm 0.12$ & $0.63 \pm 0.22$ & $0.91 \pm 0.32$ & $0.91 \pm 0.22$ \\
\hline $\mathrm{b}$ & $\mathrm{Cd}-25$ & $1.66 \pm 0.21$ & $0.65 \pm 0.20$ & $0.71 \pm 0.19$ & $0.68 \pm 0.17$ & $0.95 \pm 0.22$ & $0.91 \pm 0.17$ \\
\hline $\mathrm{c}$ & Cd-50 & $1.70 \pm 0.27$ & $0.66 \pm 0.15$ & $0.70 \pm 0.21$ & $0.71 \pm 0.19$ & $0.96 \pm 0.21$ & $1.02 \pm 0.19$ \\
\hline $\mathrm{d}$ & $\mathrm{Pb}-25$ & $0.82 \pm 0.19$ & $1.61 \pm 0.26$ & $0.66 \pm 0.17$ & $0.63 \pm 0.10$ & $0.97 \pm 0.28$ & $0.99 \pm 0.25$ \\
\hline $\mathrm{e}$ & $\mathrm{Pb}-50$ & $0.81 \pm 0.17$ & $1.89 \pm 0.22$ & $0.67 \pm 0.16$ & $0.62 \pm 0.18$ & $0.95 \pm 0.19$ & $1.03 \pm 0.28$ \\
\hline $\mathrm{f}$ & $\mathrm{Ni}-25$ & $0.85 \pm 0.19$ & $0.66 \pm 0.20$ & $1.55 \pm 0.29$ & $1.20 \pm 0.27$ & $0.96 \pm 0.21$ & $1.05 \pm 0.27$ \\
\hline $\mathrm{g}$ & $\mathrm{Ni}-50$ & $0.86 \pm 0.21$ & $0.69 \pm 0.19$ & $1.89 \pm 0.23$ & $1.43 \pm 0.29$ & $0.98 \pm 0.16$ & $0.96 \pm 0.23$ \\
\hline $\mathrm{h}$ & $\mathrm{Cd}+\mathrm{Pb}$ & $1.79 \pm 0.17$ & $1.88 \pm 0.29$ & $0.69 \pm 0.19$ & $0.72 \pm 0.14$ & $0.96 \pm 0.17$ & $0.92 \pm 0.21$ \\
\hline $\mathrm{i}$ & $\mathrm{Cd}+\mathrm{Ni}$ & $1.78 \pm 0.28$ & $0.69 \pm 0.11$ & $1.83 \pm 0.12$ & $1.53 \pm 0.18$ & $0.96 \pm 0.16$ & $0.99 \pm 0.24$ \\
\hline $\mathrm{j}$ & $\mathrm{Ni}+\mathrm{Pb}$ & $0.88 \pm 0.18$ & $1.89 \pm 0.23$ & $1.85 \pm 0.18$ & $1.64 \pm 0.25$ & $0.89 \pm 0.21$ & $0.96 \pm 0.19$ \\
\hline $\mathrm{k}$ & $\mathrm{Cd}+\mathrm{Ni}+\mathrm{Pb}$ & $1.82 \pm 0.27$ & $1.85 \pm 0.23$ & $1.86 \pm 0.21$ & $1.61 \pm 0.27$ & $0.99 \pm 0.19$ & $1.04 \pm 0.21$ \\
\hline
\end{tabular}

TF values represent means \pm SEMs $(n=6)$ of the samples collected after 30 days of plant exposure. In column 2 , the numbers in front of the metal show the concentration $\left(\mu \mathrm{mol} \mathrm{L}{ }^{-1}\right)$ at which the plants were exposed. Mixed heavy metals were all at concentration $25 \mu \mathrm{mol} \mathrm{L}-1$ 

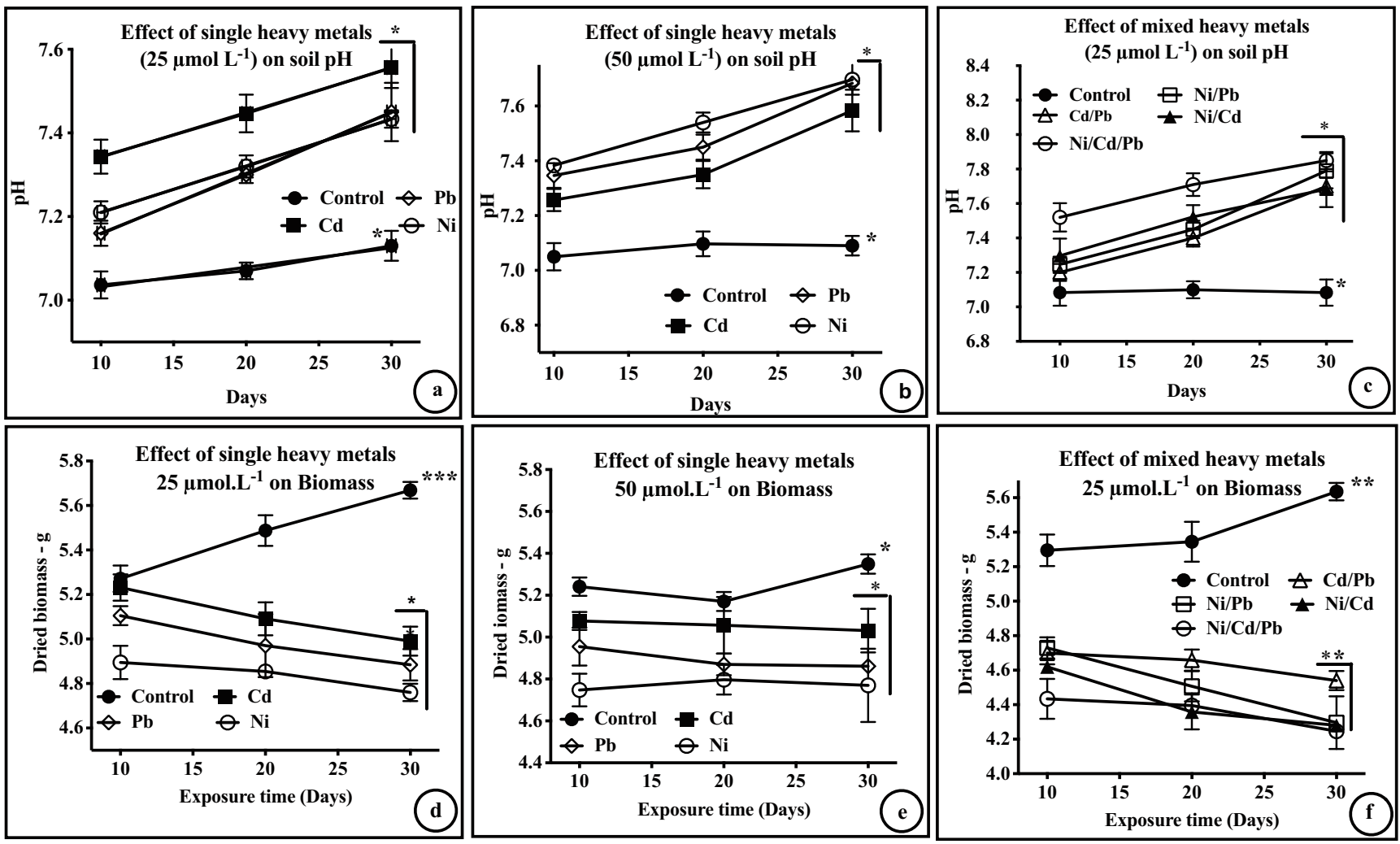

Fig. 2 Heavy metal effect on the soil $\mathrm{pH}$ and biomass: Effect of heavy metals on soil $\mathrm{pH} \mathbf{a}-\mathbf{c}$ and biomass $\mathbf{d}-\mathbf{f}$ of Conocarpus lancifolius. The changes in $\mathrm{pH}$ and biomass in response to single and mixed heavy metals

Plant roots have selective uptake capabilities together with the translocation, bioaccumulation, and degradation abilities of the entire plant body (Rezvani and Zaefarian 2011). In phytostabilization process, roots bind the contaminants in the soil matrix, thus reducing their bioavailability. Plants also immobilize metal contaminants through absorption and accumulation causing precipitation in the root zone. This makes the accumulation of HM higher in roots. In addition, phytovolatilization through the overground parts of the plant is a common process lowering the concentration of HM in leaves and stems compared with roots (Tangahu et al. 2011).

Plants that have BAFs and TFs $>1$, metal concentrations of $1000-10,000 \mathrm{mg} \mathrm{kg}^{-1}$ in the aerial parts of the dried plant material, are classified as metal hyperaccumulators and five families of plants (Brassicaceae, Rubiaceae, Cunoniaceae, Salicaceae, and Euphorbiaceae) have been identified as hyperaccumulators of heavy metals (Van der Pas and Ingle 2019). Thlaspi elegans, a known hyperaccumulator, can accumulate $13,591-15,693 \mathrm{mg} \mathrm{kg}^{-1}$ of $\mathrm{Ni}$, while the hyperaccumulator Vaccinium myrtillus L. is known to accumulate from 274 to $1,159 \mathrm{mg} \mathrm{kg}^{-1}$ of Mn (Kula et al. 2018). Thus far, 400 plants have been classified as hyperaccumulators (Mahajan and Kuashal 2018). The BAFs for $C$. lancifolius were $>1$ (Table 2) for plants exposed to single or mixed HMs (i.e., $\mathrm{Cd}, \mathrm{Pb}$, and $\mathrm{Ni}$, at 25 or $50 \mu \mathrm{mol}$ were non-significant (t-test; $* p>0.05 ; n=5$ ). Data were compared with the respective control data (gp-a). ${ }^{*}$, insignificant differences $\left({ }^{*} p>0.05\right)$

$\mathrm{L}^{-1}$ ) indicating that $C$. lancifolius has a significant capacity to absorb and accumulate HMs, and can therefore be classified as a hyperaccumulator. The BAF, EF, and TF values were calculated as given above (line 182-186). The plants found in heavily polluted areas are known to have the values of BAF and TF $>1$ (Alhemaiti et al. 2018). In the present studies, exposures to HMs, the BAFs of Mn, a natural element found in soil, did not change, indicating its minimal toxicity to the photosynthetic apparatus of the plant. The BAFs for Fe, another natural element, which is absorbed from the rhizosphere as $\mathrm{Fe}^{2+}$, also remained unchanged, indicating that it does not affect the oxidative and photosynthetic status of the plant. Fe is an essential component of antioxidant enzymes such as catalase, ascorbate peroxidase, glutathione S-transferase (GST), superoxidase dismutase (SOD), and combats the OS generated by exposure to HMs; it also elevates the activities of these enzymes (Bielen et al. 2013). The BAFs for Se also remain unchanged. The $\mathrm{BAFs}$ for $\mathrm{Fe}, \mathrm{Mg}$, and $\mathrm{Se}$ were $>1$, which signifies efficient absorption of these metals in plant's defense against the OS induced by the HMs. The BAFs for mixed HMs at $25 \mu \mathrm{mol} \mathrm{L}{ }^{-1}$ were comparable with those of plants exposed to single $\mathrm{HMs}$ at $50 \mu \mathrm{mol} \mathrm{L} \mathrm{L}^{-1}$, indicating higher toxicity and OS induced by the mixed HMs.

The fact that the EF (Table 2) was the highest $(>2)$ for the mixed HMs, suggests a synergistic effect of the HMs. The 

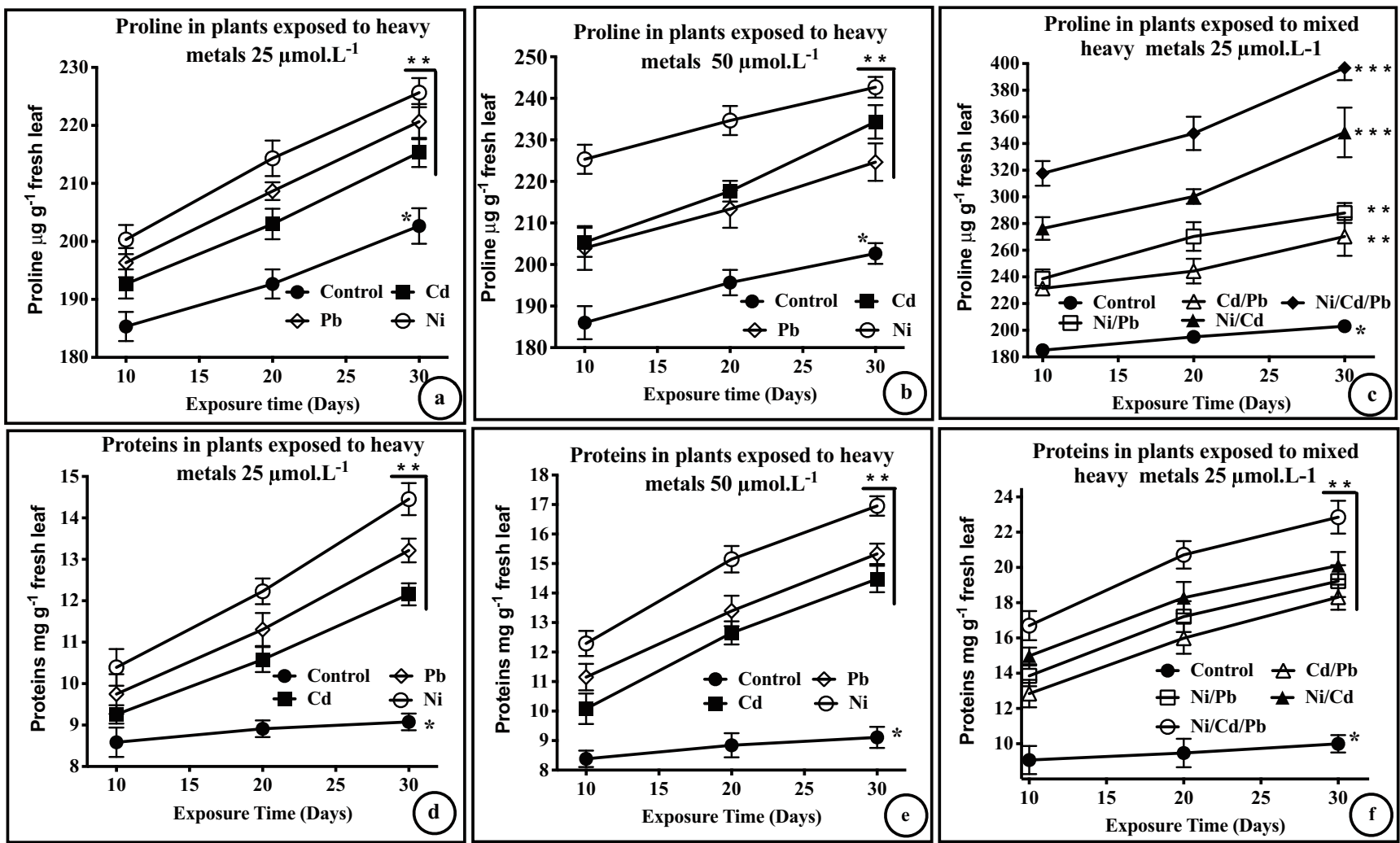

Fig. 3 Accumulation of antioxidants in response to heavy metal stress. Accumulation of proteins $\mathbf{a}-\mathbf{c}$ and proline $\mathbf{d}-\mathbf{f}$ in plants exposed to single $\left(25\right.$ or $\left.50 \mu \mathrm{M} \mathrm{L}^{-1}\right)$ and mixed $\left(25 \mu \mathrm{M} \mathrm{L}^{-1}\right)$ heavy metals. ** $(p<0.01)$ and $* * *(p<0.001)$ represent significant and highly significant

synergistic and antagonistic effects of multi-metal contaminated soil are due to an interaction between essential and nonessential metals, toxic and non-toxic metals polluting the soil (Ucuncu et al. 2014). The single $\mathrm{HMs} \mathrm{Cd}, \mathrm{Pb}$, and $\mathrm{Ni}$, and antioxidant metals $\mathrm{Fe}, \mathrm{Mg}$, and Se all had EFs $>1$. The antioxidant HMs further improved the plant defenses. The higher EFs indicate the greater absorption or accumulation of the HMs, distinguishing C. lancifolius as a hyperaccumulator of HMs. For the plants treated with mixed HMs, the higher EF ( $>2$, Table 2$)$ and TF ( $>1.8$, Table 3 ) values, relative to the BAF ( $>1$, Table 2), suggest their enhanced translocation and accumulation in the plant. The EFs and TFs were both $>1$ for mixed HMs, supporting the accumulation and translocation of the HMs in the aerial parts of the plant. The toxicity of the HMs is indicated by an amplified absorption of the antioxidant Se (EF 1.61, mixture of three mixed HMs). Huang et al. (2019) reported an increased uptake of Se in response to the OS induced by Cd. A nonsignificant increase ( $p>0.05, t$-test and ANOVA, compared with the control group) in the EF for $\mathrm{Fe}$ and unchanged $\mathrm{EF}$ for $\mathrm{Mg}$ also suggests that these metals have a defensive role against OS (Table 2). The elements involved in photosynthesis, respiration, and $\mathrm{N}$ assimilation (such as Fe and $\mathrm{Mg}$ ) help to protect photosynthetic apparatus and improve plant growth by increasing tolerance to HMs. accumulations, respectively. Data were compared with the respective control data (group a) and a Student's $t$-test $(n=6)$ was used to determine the $\mathrm{p}$-values

The fact that the BAF, EF, and TF values were $>1$ for plants treated with HMs alone and in mixtures indicates that C. lancifolius is an HM hyperaccumulator, and can thus be used for the phytoremediation of contaminated soils. An increased TF ( $>1$, Table 3$)$ indicates good translocation of HMs in hyperaccumulator plants (Kumar et al. 2018).

For plants exposed to $\mathrm{Pb}$ alone at 25 or $50 \mu \mathrm{mol} \mathrm{L}^{-1}$, the $\mathrm{TF}$ for $\mathrm{Pb}$ was significantly elevated $(p<0.02, t$-test, groups-d, e compared with the control; Table 3), indicating that C. lancifolius is a good translocator of $\mathrm{Pb}$. In mixtures of $\mathrm{Pb}$ with other $\mathrm{HMs}$, the TF for $\mathrm{Pb}$ was significantly elevated $(p<$ $0.01 ; t$-test; groups-h, $\mathrm{j}, \mathrm{k}$; compared with the control; Table 3). Based on the TFs (Table 3), Pb translocation was significantly elevated ( $t$-test, $p<0.03, \mathrm{df}=5$ ) from 0.85 in the control to 1.61 in group-d and 1.89 in group-e, (that is, at both the low and high concentrations of $\mathrm{Pb}, 25$ and $50 \mu \mathrm{mol} \mathrm{L}{ }^{-1}$, respectively). The higher TF values in plants treated with mixed HMs suggest a synergistic effect of the HMs. Our results reveal a greater change in $\mathrm{Pb}$ translocation (groups- $\mathrm{d}, \mathrm{e} ; p$ $=0.01, \mathrm{n}=6$, ANOVA) than in $\mathrm{Ni}$ or $\mathrm{Cd}$ translocation (Table 3). Pb mixed with other HMs also increased the translocation of $\mathrm{Cd}$ and $\mathrm{Ni}$ in plants (Table 3 , groups-h, j, k). Thus, the exposure of the plants to $\mathrm{Pb}$, mixed with $\mathrm{Cd}$ or $\mathrm{Ni}$, (groups-h, j, k) at $25 \mu \mathrm{mol} \mathrm{L}^{-1}$, resulted in an accumulation 
of $\mathrm{Pb}$ that was comparable to the plants exposed to $\mathrm{Pb}$ alone at a higher concentration $\left(50 \mu \mathrm{mol} \mathrm{L}{ }^{-1}\right.$, group-e). An exposure of the plants to the higher concentration of the single $\mathrm{HM} \mathrm{Cd}$ (50 $\mu \mathrm{mol} \mathrm{L}{ }^{-1}$, group-c) resulted in a TF of 1.7 , which was highly significantly elevated $(t$-test, $\mathrm{p}<0.01, \mathrm{df}=5$ ) relative to the control. Therefore, $C$. lancifolius is an excellent accumulator or translocator of $\mathrm{Cd}, \mathrm{Ni}$, and $\mathrm{Pb}$ (Table 2, 3).

The presence of one metal may affect the availability of another in the plant, indicating antagonistic or synergistic behaviors of metals (Raiesi and Sadeghi 2019). Thus, $\mathrm{Pb}$ and $\mathrm{Ni}$ were shown to have a synergistic effect on the translocation and accumulation of $\mathrm{Cd}$. When $\mathrm{Cd}$ co-occurs with $\mathrm{Ni}, \mathrm{Cd}$ absorption is stronger, and $\mathrm{Cu}$ has been shown to increase the toxicity of $\mathrm{Zn}$ in barley (Luo and Rimmer 1995). However, different oxidation states may make the metals less toxic by affecting their solubility and their bioavailability (Abedin et al. 2002).

Cross-tolerance of HMs is uncommon. For example, a species tolerant to $\mathrm{Zn}$ may be killed by $\mathrm{Cu}$. However, some grasses and leguminous plants like Lathyrus sativus are known for their co-tolerance toward HMs (Liu et al. 2015; Abdelkarim et al. 2019). Nicholls and Mal (2003) reported that a combination of $\mathrm{Pb}$ and $\mathrm{Cu}$ kills the leaves and stems of Lythrum salicaria. In a study of six HMs in maize, the order of toxicity was established to be $\mathrm{Cd}>\mathrm{Co}>\mathrm{Hg}>\mathrm{Mn}>\mathrm{Pb}>$ Cr (Ghani 2010). We have previously reported the effect of HMs on the C. lancifolius photosynthetic apparatus (Redha et al. 2019).

Soil salinity is a persistent issue in Kuwait and the salinity varies with the geomorphological landscape (Redha et al. 2019; Bannari et al. 2020). Soil salinity increases the availability and toxicity of $\mathrm{Cd}$ and decreases the soil microbial respiration rate, microbial biomass, and enzyme activity (Raiesi and Sadeghi 2019). Metal availability from soil is known to depend on the soil properties, including solubility and soil surface area, and soil pH can significantly affect the accumulation of HMs in plants (Khatun et al. 2016; Alhemaiti et al. 2018). Soil pH is also an important factor for the growth and diversity of rhizospheric bacterial communities, and for the soil organic matter content, which are required for soil improvement and plant growth (Wang et al. 2019). Our results showed that soil $\mathrm{pH}$ was non-significantly elevated ( $t$-test, $p>$ 0.05 , df $=5$, compared with the control group) when C. lancifolius plants were exposed to single or mixed HMs (Fig. 2a-c).

Although a change in $\mathrm{pH}$ may have an insignificant effect on plant growth, its effects on rhizobacterial or fungal growth may be important; rhizobacteria and fungi play important roles in plant resistance to HM toxicity, by stimulating root exudates, thus affecting plant growth and biomass (Harter 1983; Šmejkalová et al. 2003; Friedlova 2010). For example, siderophores produced by soil microbiota improve the bioavailability of metals for plants (Huyer and Page 1988).
Rhizodeposition of carbon may account for $5 \%$ of the total photosynthetically fixed carbon, but its composition and contents are sensitive to bacterial or fungal diversity. The concurrence of the rhizospheric microbiome and soil organic matter may control soil $\mathrm{pH}$ and transform or detoxify HMs (Berg and Smalla 2009). Siripan et al. (2018) demonstrated the use of rhizospheric bacteria for $\mathrm{Cd}$ toxicity alleviation in plants.

In our study, a nonsignificant elevation ( $t$-test, $p>0.05$, df $=5$, control group compared with the treated group) was observed in the soil $\mathrm{pH}$ (Fig. $2 \mathrm{a}-\mathrm{c}$ ). Numerous factors may be involved in regulating soil $\mathrm{pH}$. First, this regulation may be due to alterations in the soil physicochemical composition induced by the HMs, altering rhizospheric microbial composition and communities. Second, the regulation may change the oxidative state of the HM, making it more or less toxic. Thirdly, this regulation may be a result of the exudates from the plant roots in response to HM stress. Lastly, soil pH may induce tissue-specific transcriptional changes in ion transporters, affecting the $\mathrm{Na}^{+} / \mathrm{K}^{+}$ratio (Elda et al. 2019).

Acidosis of soil can be triggered by the secretion of acidic components, such as shikimic, gallic, fumaric, acetic, oxalic, glutamic, and succinic acid, which significantly increases the soil microbial activity (Javed et al. 2017; Ray et al. 2017). However, there is an evolutionary divergence between species in terms of adaptive root exudation (Bowsher et al. 2016). Therefore, the control of soil $\mathrm{pH}$ is multifaceted, and not only controls the diversity of rhizospheric bacterial communities but also affects the availability of plant nutrients. The soil in Kuwait, in which C. lancifolius naturally grows and thrives, is moderately alkaline. In addition, Kuwait desert temperatures range from 10 to $50^{\circ} \mathrm{C}$, and higher temperatures have been shown to help thermophilic bacteria and fungi thrive and produce antioxidant enzymes; an example of this is the SOD isolated from the thermophilic Geobacillus stearothermophilus (Gligic et al. 2000; Afzal et al. 2011). The soil in Kuwait is known to contain a diversity of thermophilic and moderately thermophilic bacteria, in the genera Amycolatopsis, Chelativorans, Isoptericola, Nocardia, Aeribacillus, Aneurinibacillus, Brevibacillus, Geobacillus, Kocuria, Marinobacter, and Paenibacillus (Al-Mailem et al. 2015). This microbial diversity plays an important role in the phytoremediation of soil contaminated with HMs.

The suitability of the experimental environment was also reflected by a nonsignificant decrease ( $t$-test, $p>0.05, \mathrm{df}=5$ ) in the biomass of $C$. lancifolius in response to single or mixed HM stress (Fig. 2d-f). Although $\mathrm{Pb}$ and $\mathrm{Cd}$, at very low concentrations, are reported to be very toxic for plant growth (Ghani (2010), C. lancifolius seems to be tolerant and able to resist the toxicity of these single metals at high concentrations of 25 and $50 \mu \mathrm{mol} \mathrm{L}{ }^{-1}$, corresponding to 7.70 and $15.42 \mathrm{mg} \mathrm{L}^{-1}$, respectively. In C. lancifolius, the long and highly branched root architecture augments the uptake of nutrients and other components from the soil. All of the above characteristics make $C$. lancifolius a remarkably suitable plant 
for the phytoremediation of crude-oil-polluted soil. Many fastgrowing plants in the Brassicaceae family are good hyperaccumulators of HM (Ashraf et al. 2011), while plants, such as Sedum alfredii, are hyperaccumulators of more than one metal, e.g., Cd and Zn (Chibuike and Obiora 2014).

The toxicity of HMs in soil affects the morphology, biochemistry, biomass, growth, and development of plants (Zhang et al. 2011; Ghavri and Singh 2012; Gautam et al. 2016; Redha et al. 2019). In general, HMs reduce the biomass of plants and microbiomes by affecting the major metabolic processes, such as those involved in photosynthesis, production of growth hormones, uptake of micronutrients, and water interactions (Vernay et al. 2007; Rodriguez et al. 2012). In the present study, in exposure response to single HMs at 25 or $50 \mu \mathrm{mol} \mathrm{L}{ }^{-1}$, a nonsignificant reduction ( $t$-test, $p>0.05, \mathrm{df}=$ 5 ) in plant biomass (Fig. 2d, e) was observed, comparable to that in plants exposed to mixed HMs at $25 \mu \mathrm{mol} \mathrm{L}^{-1}$ (Fig. 1f). This implies that minimal cell injury occurs in plants in response to single HM stress.

The above results prompted an investigation into other parameters that may be involved in the protection of C. lancifolius against HM stress. In plants, the amino acid proline regulates reactive oxygen species (ROS) and reactive nitrogen species (RNS) production, and accumulates under environmental stress, especially under drought and salt stress conditions (Székely et al. 2008; Liang et al. 2013; Mairiam et al. 2019; Hasanuzzman et al. 2020). Thus, the osmoprotective role of proline under abiotic and HM stress is well documented (Hossain et al. 2014).

In the present study, osmo-proline was found to significantly increase (t-test, $p<0.05$, df $=5$ ) in response to both concentrations ( 25 and $50 \mu \mathrm{mol} \mathrm{L}-1)$ following exposure to the single HMs (Fig. 3a, b). Proline accumulation was the highest in response to exposure to mixed HMs (groups-h-k, highly significant, $t$-test, $p<0.02, \mathrm{df}=5$ ), which indicates augmented defenses against OS, caused by the mixed HMs (Fig. 3c). The HM-induced formation of free radicals is encountered by an increased interaction with proteins and carbohydrates for phyto-chelation, and altering anti-oxidant enzyme in plants (Chen et al. 2018; Kozal et al. 2018; Xu et al. 2016). In some plants, HMs such as $\mathrm{Cd}$ induce upregulation of certain genes that produce proteins which are used in antioxidant defense mechanisms and in the detoxification of the HMs (Chen et al. 2019).

The protein content of the plants exposed to HMs was significantly elevated ( $p<0.05, t$-test) in response to both concentrations of the single HMs (Fig. 3d, e, compared with the control group), and protein accumulation was significantly elevated $(p<0.03, \mathrm{n}=6, t$-test) when plants were exposed to the mixed HMs (Fig. 3f). The accumulation of proteins may offer a defense against the OS caused by HMs, via chelation with the sulfhydryl groups of proteins, thus detoxifying the HMs (Mukhtiar et al. 2017). Specifically, Hsp70s is a multifunctional heat shock protein that is a central component of transmembrane protein transport; it also helps in protein folding in the native state, thus stabilizing multiple proteins (Mayer and Bukau 2005). In plants, $\mathrm{Pb}$ is known to upregulate $\mathrm{Hsp} 70 \mathrm{~s}$, and this upregulation is a marker for $\mathrm{Pb}$ induced stress (Esposito et al. 2012). An upregulation of defense proteins and detoxification triggered by $\mathrm{Cd}$ is also known (Ahsan et al. 2007). Thus, our findings show that C. lancifolius is an effective hyperaccumulator of HMs, combatting HM-induced OS by accumulating proline, proteins, and antioxidant metals. These findings are important for the phytoremediation of HM-contaminated soils in Kuwait.

\section{Conclusion}

The bioaccumulation, extraction, and transcription factors for heavy metals were all $>1$ indicating $C$. lancifolius is a hyperaccumulator when exposed to single or mixed HMs, and it can be used for the phytoremediation of crude oil contaminated soil and particulate matter that are hazardous to human health. Our results indicated that an exposure of the plants to mixed heavy metals was more detrimental than single heavy metal at the same concentration. The heavy metals uptake by $C$. lancifolius was not only concentration dependent but also depended if the plant was exposed to single or mixed heavy metals. In response to the oxidative stress imposed by the heavy metals, the plant defenses were upregulated by an elevation of antioxidants such as $\mathrm{Fe}, \mathrm{Mg}$, Se, osmoprotective proline, and proteins. The rhizospheric bacteria maintained the soil $\mathrm{pH}$, and it was not conceited by the heavy metals resulting in an insignificant decrease in the plant biomass. Furthermore, the plant survived in the harsh desert environment and could thus be widely introduced for not only phytoremediation but also for greenery, shade, and to stabilize sand dunes. Further studies are warranted to examine the plant-metal interaction of other heavy metals present in crude oil.

Acknowledgements This research was funded by the Kuwait Foundation for the Advancement of Science (KFAS-Grant number P214-42SL-05) for which the authors are thankful. The funding authority KFAS had no role in the design of the study, collection, analysis and interpretation of data or in writing the manuscript. We gratefully acknowledge the use of instrumental facilities, and assistance from staff, at the National Unit for Environmental Research and Services (SRUL01/13), Kuwait University. The authors are thankful to J. Jose and D. Saju for their technical support.

Author's contributions AR contributed to the plant breeding, bench work, growth conditions, plant propagation, and writing of the first draft of the manuscript. RH conceived the research idea, received the research grant, and contributed to project management and manuscript writing. MA analyzed the results, supervised JJ and DS, and critically finalized the first draft of the manuscript.

Funding This research was funded by the Kuwait Foundation for the Advancement of Science (Grant number P214-42SL-05). 
Data availability - The datasets used and/or analyzed during the current study are available from the corresponding author on reasonable request.

- All data generated or analyzed during this study are included in this published article.

- Data sharing is not applicable to this article as no datasets were generated or analyzed during the current study.

\section{Compliance with ethical standards}

\section{Ethics approval and consent to participate Not applicable.}

\section{Consent for publication Not applicable.}

Competing interests The authors declare that they have no competing interests.

Open Access This article is licensed under a Creative Commons Attribution 4.0 International License, which permits use, sharing, adaptation, distribution and reproduction in any medium or format, as long as you give appropriate credit to the original author(s) and the source, provide a link to the Creative Commons licence, and indicate if changes were made. The images or other third party material in this article are included in the article's Creative Commons licence, unless indicated otherwise in a credit line to the material. If material is not included in the article's Creative Commons licence and your intended use is not permitted by statutory regulation or exceeds the permitted use, you will need to obtain permission directly from the copyright holder. To view a copy of this licence, visit http://creativecommons.org/licenses/by/4.0/.

\section{References}

Abdelkarim S, Jebara SH, Saadani O et al (2019) Heavy metal accumulation in Lathyrus sativus growing in contaminated soils and identification of symbiotic resistant bacteria. Arch Microbiol 201:107121. https://doi.org/10.1007/s00203-018-1581-4

Abedin MJ, Feldmann J, Meharg AA (2002) Uptake kinetics of arsenic species in rice plants. Plant Physiol 128:1120-1128. https://doi.org/ 10.1104/pp.010733

Afzal M, Oommen S, Al-Awadi S (2011) Transformation of chenodeoxycholic acid by thermophilic Geobacillus stearothermophilus. Biotechnol Appl Biochem 58:250-255. https://doi.org/10.1002/bab.34

Ahsan N, Lee SH, Lee DG, Lee H, Lee SW, Bahk JD, Lee BH (2007) Physiological and protein profiles alternation of germinating rice seedlings exposed to acute cadmium toxicity. Comp Rend Biol 330:735-746. https://doi.org/10.1016/j.crvi.2007.08.001

Alhemaiti A, Jiang J, Li D et al (2018) The interaction of metal concentrations and soil properties on toxic metal accumulation of native plants in vanadium mining area. J Environ Manag 222:216-226. https://doi.org/10.1016/j.jenvman.2018.05.081

Al-Mailem DM, Kansour MK, Radwan SS (2015) Moderately thermophilic, hydrocarbonoclastic bacterial communities in Kuwaiti desert soil: enhanced activity via $\mathrm{Ca}\left(2^{+}\right)$and dipicolinic acid amendment. Extremophiles. 19:573-583. https://doi.org/10.1007/s00792-0150739-0

Ashraf MY, Azhar N, Ashraf M, Hussain M, Arshad M (2011) Influence of lead on growth and nutrient accumulation in canola (Brassica napus L.) cultivars. J Environ Biol 32(5):659-666

Bannari A, Zahra M, Al-Ali ZM (2020) Assessing climate change impact on soil salinity dynamics between 1987-2017 in arid landscape using landsat TM, ETM+ and OLI data. Remote Sens 12:2794. https://doi.org/10.3390/rs12172794

Berg G, Smalla K (2009) Plant species and soil type cooperatively shape the structure and function of microbial communities in the rhizosphere. FEMS Microbiol Ecol 68:1-13. https://doi.org/10.1111/j. 1574-6941.2009.00654.x

Bergman I, Loxley R (1970) New spectrophotometric method for the determination of proline in tissue hydrolysates. Anal Chem 42: 702-706. https://doi.org/10.1021/ac60289a036

Bielen A, Remans T, Vangronsveld J, Cuypers A (2013) The influence of metal stress on the availability and redox state of ascorbate, and possible interference with its cellular functions. Int J Mol Sci 14: 6382-6413. https://doi.org/10.3390/ijms14036382

Bowsher AW, Ali R, Harding SA, Tsai CJ, Donovan LA (2016) Evolutionary divergence in roots exudate composition among ecologically-contrasting Helianthus species. PLoS One 11: e0148280. https://doi.org/10.1371/journal.pone.0148280

Bradford MM (1976) A rapid and sensitive method for the quantitation of microgram quantities of proteins utilizing the principle of proteindye binding. Anal Biochem 72:248-254. https://doi.org/10.1016/ 0003-2697(76)90527-3

Carillo P, Gibon Y (2011) Protocol: Extraction and determination of proline. https://www.researchgate.net/publication/211353600 PROTOCOL_Extraction_and_determination_of_proline

Chaney RL, Malik M, Li YM, Brown SL, Brewer EP, Angle JS, Baker AJM (1997) Phytoremediation of soil metals. Curr Opin Biotechnol 8:279-284

Chen J, Liu YQ, Yan XW, Wei GH, Zhang JH, Fang LC (2018) Rhizobium inoculation enhances copper tolerance by affecting copper uptake and regulating the ascorbate-glutathione cycle and phytochelatin biosynthesis-related gene expression in Medicago sativa seedlings. Ecotox Environ Safe 162:312-323. https://doi. org/10.1016/j.ecoenv.2018.07.001

Chen S, Liu Y, Deng Y, Liu Y, Dong M, Tian Y, Sun H, Li Y (2019) Cloning and functional analysis of the VcCXIP4 and VcYSL6 genes as Cd-regulating genes in blueberry. Genes 686:104-117. https:// doi.org/10.1016/j.gene.2018.10.078

Chibuike GU, Obiora SC (2014) Heavy metal polluted soils: effect on plants and bioremediation methods. Appl Environ Soil Sci 1-12. doi: https://doi.org/10.1155/2014/752708

Chinedu E, Chukwuemeka CK (2018) Oil spillage and heavy metals toxicity in the Niger Delta, Nigeria. J Health Poll 8:180905. https://doi.org/10.5696/22156-9614-8.19.180905

Elda AA, Aizubaidy HS, de Zélicourt A et al (2019) Phylogenetically diverse endophytic bacteria from desert plants induce transcriptional changes of tissue specific ion transporters and salinity stress in Arabidopsis thaliana. Plant Sci 280:228-240. https://doi.org/10. 1016/j.plantsci.2018.12.002

Esposito S, Sorbo S, Conte B, Basile A (2012) Effects of heavy metals on ultrastructure and HSP70s induction in the aquatic moss Leptodictyum riparium Hedw. Int J Phytorem 14:443-455. https:// doi.org/10.1080/15226514.2011.620904

Farrag K, Senesi N, Soler-Rovira P et al (2011) Effects of selected soil properties on phytoremediation accplicability for heavy metal contaminated soils in the Apulia region, Southern Italy. Environ Monit Assess 84:65093-66606. https://doi.org/10.1007/s10661-0112444-5

Friedlova M (2010) The influence of heavy metal on soil biological properties. Soil Water Res 5:21-27

Gao Y, Kang L, Zhang Y, Feng J, Zhu L (2019) Toxicokinetics and toxicodynamics (TK-TD) modeling to study oxidative stressdependent toxicity of heavy metals in Zebrafish. Chemosph 220: 774-782. https://doi.org/10.1016/j.chemosphere.2018.12.197

Gautam S, Anjani K, Srivastava N (2016) In vitro evaluation of excess copper affecting seedlings and their biochemical characteristics in 
Carthamus tinctorius L. (variety PBNS-12). Physiol Mol Biol Plants 22:121-129. https://doi.org/10.1007/s12298-016-0339-1

Ghani A (2010) Toxic effect of heavy metals on plant growth and metal accumulation in maize (Zea mays L.). Iranian J Toxicol 3:325-334 http://www.semanticscholar.org/paper/TOXIC-EFFECTS-OFHEAVY-METALS-ON-PLANT-GROWTH-ANDAbdul/ 5e8639a38b221e1a732aeaf510afea193c2d8eaa

Ghavri SV, Singh RP (2012) Growth, biomass production and remediation of copper contamination by Jatropha curcas plant in industrial wasteland soil. J Environ Biol 33:207-214

Gligic L, Radulovic Z, Zavisic G (2000) Superoxide dismutase biosynthesis by two thermophilic bacteria. Enzym Microb Technol 27: 789-792. https://doi.org/10.1016/s0141-0229(00)00302-1

Harter RD (1983) Effect of soil pH on adsorption of lead, copper, zinc, and nickel. Soil Sci Soc Amer J 47:47-51. https://doi.org/10.2136/ sssaj1983.03615995004700010009x

Hasanuzzman M, Bhuyan MHMB, Zulifqar F et al (2020) Reactive oxygen species and antioxidant defense in plants under abiotic stress: Revising the crucial role of a universal defense regulator. Antioxidants (basal) 9(8):681. https://doi.org/10.3390/ antiox 9080681

Hawrylak-Nowak B (2013) Comparative effect of selenite and selenate on the growth and selenium accumulation in lattice plants under hydroponic conditions. Plant Growth Regul 70:149-157. https:// doi.org/10.1007/s10725-013-9788-5

Horvat T, Vidaković-Cifrek Z, Oreščanin V, Tkalec M, Pevalek-Kozlina B (2007) Toxicity assessment of heavy metal mixtures by Lemna minor L. Sci Total Environ 384:229-238. https://doi.org/10.1016/j. scitotenv.2007.06.007

Hossain MA, Hoque MA, Burritt DJ et al (2014) Proline protects plants against abiotic oxidative stress: Biochemical and molecular mechanisms, Chapter 16. In: Ahmad P (ed) Oxidative Damage to Plants. Elsevier, Netherlands, pp 477-522. https://doi.org/10.1016/B978-012-799963-0.00016-2

Huang Q, Liu Y, Qin X et al (2019) Selenite mitigates cadmium-induced oxidative stress and affects $\mathrm{Cd}$ uptake in rice seedlings under different water management systems. Ecotox Environ Saf 168:486-494. https://doi.org/10.1016/j.ecoenv.2018.10.078

Huyer M, Page WJ (1988) $\mathrm{Zn} 2^{+}$increases siderophore production in Azotobacter vinelandii. Appl Environ Microbiol 54:2625-2631

Javed MT, Akram MS, Tanwir K, Javed Chaudhary H, Ali Q, Stoltz E, Lindberg S (2017) Cadmium spiked soil modulates root organic acids exudation and ionic contents of two differently Cd tolerant maize (Zea mays L.) cultivars. Ecotox Environ Saf 141:216-225. https://doi.org/10.1016/j.ecoenv.2017.03.027

Khatun A, Pal S, Mukherjee AK, Samanta P, Mondal S, Kole D, Chandra P, Ghosh AR (2016) Evaluation of metal contamination and phytoremediation potential of aquatic macrophytes of East Kolkata wetlands, India. Environ Health Toxicol 31:e2016021. https://doi. org/10.5620/eht.e2016021

Kisku GC, Barman SC, Bhargava SK (2000) Contamination of soil and plants with potentially toxic elements irrigated with mixed industrial effluents and its impact on the environment. Water Air Soil Pollut 120:121-137. https://doi.org/10.1023/A:1005202304584

Kostecki P, Behbehani M (1995) Assessment and remediation of oil contaminated soils. Proceedings of workshop, Kuwait, March 1827, Arab School of science and technology, Kuwait. New age International Limited Publisher, New Delhi, p 70 ISBN:81-2241204-1

Kozal N, Sakamoto F, Tanaka K et al (2018) Complexation of Eu(III), $\mathrm{Pb}(\mathrm{II})$, and $\mathrm{U}(\mathrm{VI})$ with a paramecium glycoprotein: Microbial transformation of heavy elemnets in the aquatic environment. Chemosphere 196:135-144. https://doi.org/10.1016/j. chemosphere.2017.12.154
Kula E, Wildová E, Hrdlička P (2018) Accumulation and dynamics of manganese content in bilberry (Vaccinium myrtillus L.). Environ Monit Assess 190:224. https://doi.org/10.1007/s10661-018-6604-8

Kumar V, Singh J, Chopra AK (2018) Assessment of plant growth attributes, bioaccumulation, enrichment, and translocation of heavy metals in water lettuce (Pistia stratiotes L.) grown in sugar mill effluent. Int J Phytorem 20:507-521. https://doi.org/10.1080/ 15226514.2017.1393391

Küpper H, Küpper FC, Spiller M (2006) Heavy metal-chlorophylls formed in vivo during heavy metal stress and degradation products formed during digestion, extraction and storage of plant material. In: Grimm B, Porro RRJ, Scheer H (eds) Chlorophyll and Bacteriochlorophylls: Biochemistry, Biophysics, Functions and Application. Springer, Dordrecht, pp 67-77 https://doi.org/10. 1007/1-4020-4516 5

Laxa M, Liebthal M, Telman W et al (2019) The role of plant antioxidant system in drought tolerance. Antioxidants (Basel) 8(4):94. https:// doi.org/10.3390/antiox8040094

Lian M, Wang J, Sun L, Xu Z, Tang J, Yan J, Zeng X (2019) Profiles and potential health risks of heavy metals in soil and crops from the watershed of Xi river in Northeast China. Ecotox Environ Saf 169: 442-448. https://doi.org/10.1016/j.ecoenv.2018.11.046

Liang X, Zhang L, Natarajan SK, Becker DF (2013) Proline mechanisms of stress survival. Antioxid Redox Signal 19:998-1011. https://doi. org/10.1089/ars.2012.5074

Liu A, Fang D, Wang C, Li M, Young RB (2015) Recovery of soil nitrification after long term zinc exposure and its co-tolerance to $\mathrm{Cu}$ in different soils. Environ Sci Pollut Res Int 22:314-319. https://doi.org/10.1007/s11356-014-3338-1

Luo Y, Rimmer DL (1995) Zinc-copper interaction affecting plant growth on a metal-contaminated soil. Environ Pollut 88:79-83. https://doi.org/10.1016/0269-7491(95)91050-U

Mahajan P, Kuashal J (2018) Role of phytoremediation in reducing cadmium toxicity in soil water. J Toxicol 3:1-16. https://doi.org/10. $1155 / 2018 / 4864365$

Mairiam L, Liebthal M, Telam W et al (2019) The role of the plant antioxidant system in drought tolerance. Antioxidants (Basel) 8(4): 94. https://doi.org/10.3390/antiox 8040094

Mayer MP, Bukau B (2005) Hsp70 chaperones: cellular functions and molecular mechanism. Cell Mol Life Sci 62:670-684. https://doi. org/10.1007/s00018-004-4464-6

McGrath SP, Zhao F (2003) Phytoextraction of metals and metalloids from contaminated soils. Curr Opin Biotechnol 14:277-282. https://doi.org/10.1016/S0958-1669(03)00060-0

Mourato MP, Moreira IN, Leitão I, Pinto F, Sales J, Martins L (2015) Effect of heavy metals in plants of the genus Brassica. Int J Mol Sci 16:17975-17998. https://doi.org/10.3390/ijms160817975

Mukhtiar M, Jan SU, Ullah I et al (2017) The role of glutathione, cysteine and D-penicillamine in exchanging Palladium and Vanadium metals from albumin metal complex. Pak J Pharm Sci 30(6):2405-2410

Nanda R, Agrawal V (2016) Elucidation of zinc and copper induced oxidative stress, DNA damage and activation of defense system during seed germination in Cassia angustifolia Vahl. Environ Exp Bot 125:31-41. https://doi.org/10.1016/j.envexpbot.2016.02.001

Nicholls AM, Mal TK (2003) Effect of lead and copper exposure on growth of an invasive weed, Lythrum salicaria L. (Purple Loosestrife). Ohio J Sci 103:129-133 Corpus ID: 19217664

Noormohamadi HR, Fathi MR, Ghaedi M et al (2018) Potentiality of white-rot fungi in biosorption of nickel and cadmium: Modeling optimization and kinetics study. Chemosphere 216:124-130. https://doi.org/10.1016/j.chemosphere.2018.10.113

Patra RC, Rautray AK, Swarup D (2011) Oxidative stress in lead and cadmiuim toxicity and its amelioration. Vet Med Int 2011:457327, 9 pages. https://doi.org/10.4061/2011/457327

Raiesi F, Sadeghi E (2019) Interactive effect of salinity and cadmium toxicity on soil microbial properties and enzyme activities. Ecotox 
Environ Saf 168:221-229. https://doi.org/10.1016/j.ecoenv.2018. 10.079

Rasheed F, Zafar Z, Waseem ZA, Rafay M, Abdullah M, Salam MMA, Mohsin M, Khan WR (2019) Phytoaccumulation of Zn, Pb, and Cd in Conocarpus lancifolius irrigated with wastewater: does physiological response influence heavy metal uptake? Int J Phytoremed 22(3):287-294. https://doi.org/10.1080/15226514.2019.1658711

Ray S, Mishra S, Bisen K, Singh S, Sarma BK, Singh HB (2017) Modulation in phenolic root exudate profile of Abelmoschus esculentus expressing activation of defense pathway. Microbiol Res 207:100-107. https://doi.org/10.1016/j.micres.2017.11.011

Redha A, Al-Mansour N, Suleman P et al (2011) Leaf traits and histochemistry of trichomes of Conocarpus lancifolius a Combretaceae in semi-arid conditions. Amer J Plant Sci 2:165-174. https://doi.org/ 10.4236/ajps.2011.22018

Redha A, Al-Hasan R, Jose J et al (2019) The photosynthetic apparatus of Conocarpus lancifolius Engl. (Combretaceae) suffers damage in soil contaminated with heavy metals. Can J Bot 97:179-189. https://doi. org/10.1139/cjb-2018-0047

Rezvani M, Zaefarian F (2011) Bioaccumulation and translocation factors of cadmium and lead Aeluropus littoralis. Aust J Agric Eng 2(4):114-119 ISSN: 18369448

Rodriguez E, Santos C, Azevedo R, Moutinho-Pereira J, Correia C, Dias MC (2012) Chromium (VI) induces toxicity at different photosynthetic levels in pea. Plant Physiol Biochem 53:94-100. https://doi. org/10.1016/j.plaphy.2012.01.013

Sampanpanish P, Nanthavong K (2019) Effect of EDTA and NTA on arsenic bioaccumulation and translocation using phytoremediation by Mimosa pudica L. from contaminated soils. Bull Environ Contam Toxicol 102:140-145. https://doi.org/10.1007/s00128018-2502-6

Shahid M, Pourrut B, Dumat C et al (2014) Heavy-metal-induced reactive oxygen species: phytotoxicity and physicochemical changes in plants. Rev. Environ Cont Toxicol 232:1-44. https://doi.org/10. 1007/978-3-319-06746-9-1

Shanker AK, Cervates C, Loza-Tavera $\mathrm{H}$ et al (2005) Chromium toxicity in plants. Environ Int 31:739-753. https://doi.org/10.1016/j.envint. 2005.02.003

Siripan O, Thamchaipenet A, Surat W (2018) Enhancement of the efficiency of Cd phytoextraction from Chromolaena odorata, a cadmium hyperaccumulator. Int J Phytorem 20:1096-1115. https://doi. org/10.1080/15226514.2017.1365338

Skowronska M, Bielinska EJ, Szymanski K et al (2020) An integrated assessment of the long-term impact of municipal sewage sludge on the chemical and biological properties of soil. Catena 189:104484. https://doi.org/10.1016/j.catena.2020.104484

Šmejkalová M, Mikanová O, Borůvka L (2003) Effects of heavy metal concentrations on biological activity of soils microorganisms. Plant Soil Environ 49:321-326. doi: 10.17221/4131-PSE

Székely G, Abrahám E, Cséplo A et al (2008) Duplicated P5CS genes of Arabidopsis play distinct roles in stress regulation and developmental control of proline biosynthesis. Plant J 53:11-28. https://doi.org/ 10.1111/j.1365-313X.2007.03318.x

Tangahu BV, Abdullah SRS, Basri $\mathrm{H}$ et al (2011) A review of heavy metals $(\mathrm{As}, \mathrm{Pb}$, and $\mathrm{Hg}$ ) uptake by plants through phytoremediation. Int J Chem Eng 939161:31. https://doi.org/10.1155/2011/939161
Tomašević M, Rajšić S, Đorđević D, Tasić M, Krstić J, Novaković V (2004) Heavy metals accumulation in tree leaves from urban areas. Environ Chem Lett 2:151-154. https://doi.org/10.1007/s10311004-0081-8

Ucuncu E, Ozkan AD, Olmez TT et al (2014) Phytoremediation of multiply metal-contaminated environments: Synergistic and competitive effects between heavy metals during uptake and transport. Heavy Metal Remediation: Transport and Accumulation in Plants, Nova Science Publishers, InC. Book Chapter, pp 179-200. http://hdl. handle.net/11693/38360

Van der Pas L, Ingle RA (2019) Towards an understanding of the molecular basis of Nickel hyperaccumulation in plants. Plants (Basel) 8(1):11. https://doi.org/10.3390/plants8010011

Vernay P, Gauthier-Moussard C, Hitmi A (2007) Interaction and bioaccumulation of heavy metal chromium with water relation, mineral nutrition and photosynthesis in developed leaves of Lolium perenne L. Chemosphere 68:1563-1575. https://doi.org/10.1016/j. chemosphere.2007.02.052

Wang LU, Kang Y, Liang S, Chen D, Zhang Q, Zeng L, Luo J, Jiang F (2018) Synergistic effect of co-exposure to cadmium (II) and 4-nnonylphenol on growth inhibition and oxidative stress of Chlorella sorokiniana. Ecotoxicol Environ Saf 154:145-153

Wang M, Li S, Chen S et al (2019) Manipulation of the rhizosphere bacterial communities by biofertilizers is associated with mitigation of cadmium phytotoxicity. Sci Total Environ 649:413-421. https:// doi.org/10.1016/j.scitotenv.2018.08.174

Wuana RA, Okieimen FE (2011) Heavy metals in contaminated soils: A review of sources, chemistry, risks and best available strategies for remediation. Int Schol Res Netw 2011:402647. https://doi.org/10. $5402 / 2011 / 402647$

Xu S, Gong XF, Zou HL, Liu CY, Chen CL, Zeng XX (2016) Recycling agriculture wastes of ramie stalk as bioabsorbents of $\mathrm{Cd}(2+)$ removal: a kinetic and thermodynamic study. Water Sci Technol 73(2): 396-404. https://doi.org/10.2166/wst.2015.475

Yan A, Wang Y, Tan SN et al (2020) Phytoremediation: a promising approach for revegetation of heavy metal-polluted land. Front Plant Sci 11:359. 1-15. https://doi.org/10.3389/fpls.2020.00359

Zhang Y, Zheng GH, Liu P, Song JM, Xu GD, Cai MZ (2011) Morphological and physiological responses of root tip cells to $\mathrm{Fe}^{2+}$ toxicity in rice. Acta Physiol Plant 33:683-689. https://doi.org/10. 1007/s11738-010-0590-y

Zhang W, Tan NG, Fu B et al (2015) Metallomics and NMR-based metabolomics of Chlorella sp. Reveal the synergistic role of copper and cadmiuim in multimetal toxicity and oxidative stress. Metabollomics 7(3):426-438. https://doi.org/10.1039/c4mt00253a

Zoufan P, Jalali R, Hassibi P et al (2018) Evaluation of antioxidant bioindicators and growth responses in Malva parviflora $\mathrm{L}$. exposed to cadmium. Physiol Mol Biol Plants 24(6):1005-1016. https://doi. org/10.1007/s12298-018-0596-2

Publisher's note Springer Nature remains neutral with regard to jurisdictional claims in published maps and institutional affiliations. 